\title{
EL DESAPARECIDO RETABLO MAYOR DE LA IGLESIA DE SAN LUIS OBISPO DE MADRID, OBRA DEL ESCULTOR JUAN DE VILLANUEVA
}

\author{
BÁRBARA GARCía MENÉNDEZ \\ Doctora en Historia del Arte
}

Con las informaciones obtenidas de numerosas referencias documentales inéditas y de una fotografía conservada en el Archivo Moreno y hasta ahora inadvertida por otros investigadores, se presenta en este artículo un pormenorizado análisis histórico y artístico sobre el retablo mayor de la iglesia madrileña de San Luis Obispo y sus esculturas (destruidos en 1936). Se trata de uno de los conjuntos más significativos de la etapa de plenitud creativa del escultor Juan de Villanueva, destacado representante del barroco dieciochista madrileño, que acometió la obra entre 1734 y 1740.

Palabras clave: Iglesia de San Luis Obispo; Madrid; Retablo mayor; Juan de Villanueva; Barroco dieciochista.

\section{THE LOST MAIN ALTARPIECE OF THE MADRID CHURCH OF SAN LUIS OBISPO, BY THE SCULPTOR JUAN DE VILLANUEVA}

Based on information obtained from several unpublished documents and a photograph kept in the Moreno Archives - until now unnoticed by scholars-, a thorough historical and artistic study of the main altarpiece of the Madrid church of San Luis Obispo (Saint Louis Bishop) and its sculptural decoration (destroyed in 1936) is presented in this article. This is one of the most outstanding works by the sculptor Juan de Villanueva, a distinguished representative of eighteenth-century baroque art in Madrid, produced between 1734 and 1740, at the height of his creative career.

Key words: Church of Saint Louis Bishop; Madrid; Main altarpiece; Juan de Villanueva; Eighteenthcentury baroque.

La tarde del viernes 13 de marzo de 1936, en pleno ambiente prebélico, un incendio, provocado, según la información de la prensa de la época, asoló la iglesia parroquial de San Luis Obispo de Madrid, sita en la calle de la Montera, haciendo esquina con la de San Alberto (fig. 1) ${ }^{1}$.

${ }^{1}$ Como se puede comprobar en una revisión de la prensa de ese año, esta es la referencia correcta y no la de 1935 que dan M. E. Gómez-Moreno (en Tormo, 1927/1979: 147), y todos los autores posteriores que lo mencionan, segura- 


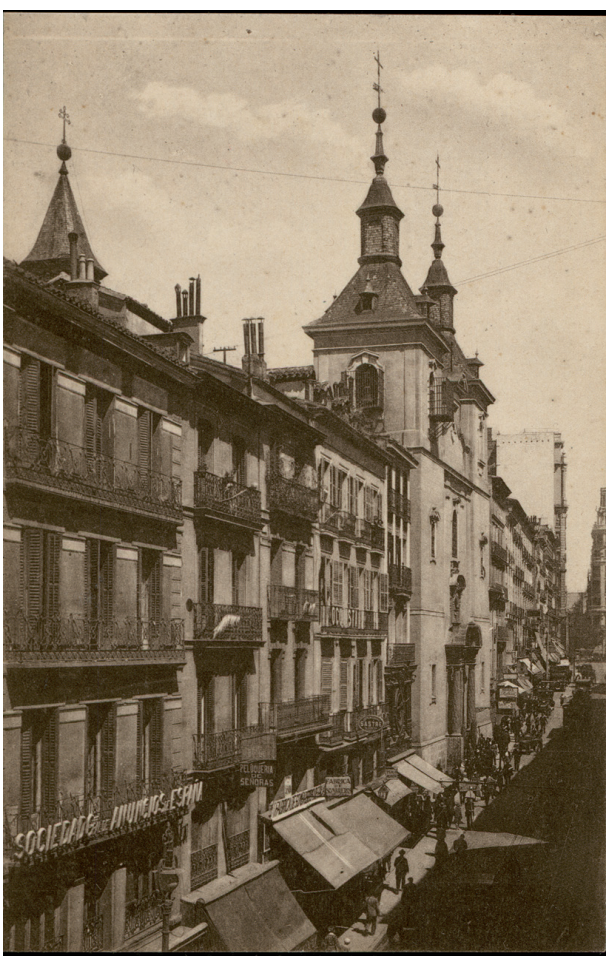

Fig. 1. Iglesia de San Luis Obispo en la calle de la Montera, ca. 1921-1933. Ayuntamiento de Madrid. Museo de Historia, inv. 31377.

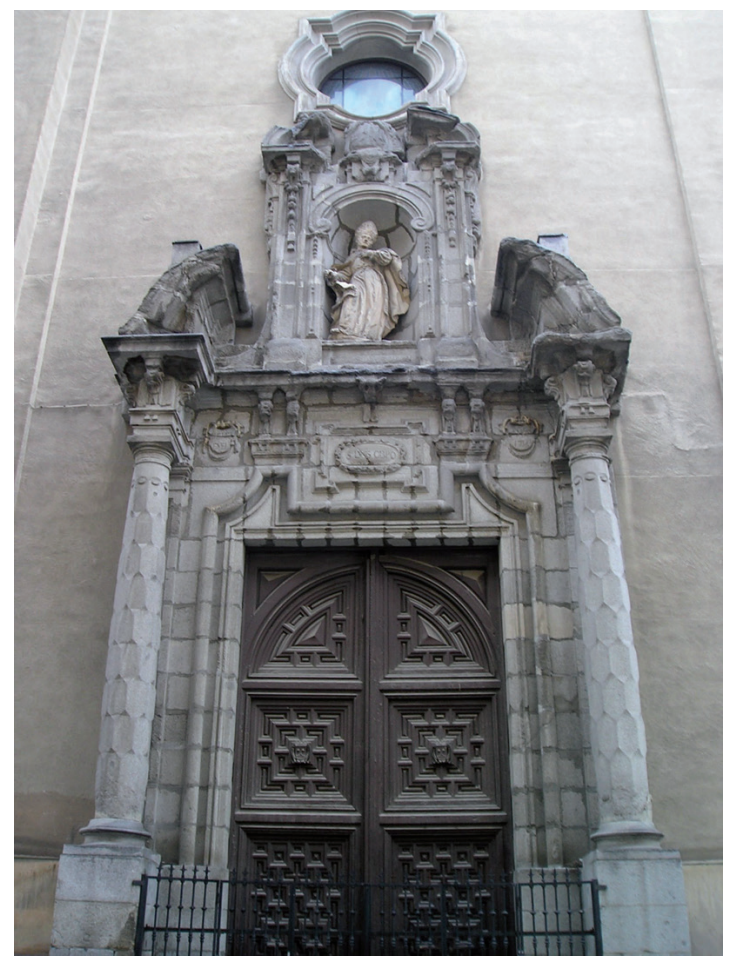

Fig. 2. Portada principal del antiguo templo de San Luis Obispo, en la iglesia del Carmen, 1720. Madrid, calle de la Salud. Fotografía de la autora.

Y aunque sus muros todavía resistirían en pie hasta su demolición en marzo de 1943 (pese a haberse desplomado la cúpula y gran parte de la bóveda por los bombardeos de la Guerra Civil)2, y su portada principal, obra de 1716 (fig. 2), se trasladaría en 1950 al templo del antiguo convento de los carmelitas calzados (donde aún hoy se conserva), aquel fuego supuso realmente el fin para un edificio del antiguo Madrid cuya historia había comenzado a mediados del siglo XVI. Y con él desapareció también su retablo mayor, diseñado y construido entre 1734 y 1740 por el escultor asturiano Juan de Villanueva y Barbales (Pola de Siero, 1681-Madrid, 1765). Sin embargo, la localización de varios testimonios documentales y de una fotografía del retablo en el Archivo Moreno nos ha permitido reconstruir su historia y analizar sus características formales y estilísticas.

mente por seguir esta fuente. Véanse, por ejemplo, La libertad, 14-III-1936: 3; 15-III: 3; 17-III: 6; 19-III: 2; 21-III: 7; 24-III: 9. El Sol, 15-III-1936: 4. El siglo futuro, 16-III-1936: 2. El Heraldo de Madrid, 16-III-1936: 5; 18-III: 2. La Época, 16-III-1936: 1. La Voz, 20-III-1936: 3. El mismo día que San Luis fue incendiada también la iglesia de San Ignacio, en la calle del Príncipe.

2 En diciembre de 1942, «unos industriales de una rica capital española» adquirieron el solar de San Luis para erigir un edificio de oficinas, por lo que unos pocos meses después, en marzo de 1943, se procedió al derribo de los restos del templo. Castán Palomar, 1942: 15. Tercero, 1943: 12. Gómez-Moreno, en Tormo, 1927/1979: 147. 


\section{La construcción del retablo}

Una vez finalizada la renovación de la iglesia antigua del XVI, abordada en el último tercio del siglo XVII y rematada aún en $1721^{3}$, la parroquia madrileña de San Luis Obispo decidió, a mediados de la década de 1730, contratar la hechura de un nuevo retablo mayor de madera dorada para el templo ${ }^{4}$.

Con él se reemplazaría al que hasta entonces había servido en la iglesia, cuyo aspecto conocemos, al menos parcialmente, gracias al lienzo Carlos II ante la Sagrada Forma (1683), del pintor barroco madrileño Pedro Ruiz González (1640-1706), hoy en el Museo de Arte de Ponce (Puerto Rico) (fig. 3). La escena que da título a la pintura se desarrolla, en efecto, ante el antiguo retablo de San Luis, anterior al de Villanueva, y que, si sus formas no son invención o fantasía del pintor, seguía los modelos del barroco castizo madrileño de mediados del siglo XVII, pues era una estructura de recargada decoración, con un cuerpo principal con columnas salomónicas y tres hornacinas, la central con un gran tabernáculo rematado en una figura de San Luis Obispo, y las laterales con sendas imágenes de San Andrés y Santo Domingo de Guzmán ${ }^{5}$. Dado que la escultura de San Luis fue contratada el 24 de abril de 1654 con el maestro Asensio de Castro, sería por entonces cuando se habría dispuesto el altar, de momento de autor desconocido, y que en la centuria siguiente sería retirado .

El nuevo retablo del siglo XVIII se ajustó con el escultor y ensamblador asturiano Juan de Villanueva, quien desde comienzos de la centuria venía desarrollando su carrera profesional en Madrid y que hacía por lo menos veinte años que era feligrés de la parroquia de San Luis, en cuya vida espiritual participaba, además, activamente como miembro de su cofradía sacramental ${ }^{7}$. Esta cercanía hubo de facilitarle seguramente la adjudicación del retablo, pero benefició asimis-

\footnotetext{
${ }^{3}$ La primera iglesia de San Luis, construida a mediados del siglo XVI, fue remodelada en la centuria siguiente a partir de una traza de planta salón de Marcos López, de 1668. La dirección de las obras correspondió a Tomás Román (1669-1682) y a sus sobrinos Matías Román y Ambrosio Sánchez (1686-1690). La reforma la rematarían, ya entre 1715-1721, Francisco Ruiz y Francisco de Lara Caballero con la hechura del último tramo de la planta, a los pies (coro, últimas capillas, dos torres, fachada y portada). Desde 1911 la parroquia quedó unida a la del Carmen, en cuya iglesia subsiste al presente y donde se conserva, en la entrada por la calle de la Salud, la que había sido portada principal de San Luis. Sobre las obras de la iglesia, sobre todo, SAltillo, 1948: 161-221. RuIz Argilés, 1953: 37-50. Tovar MARTÍN, 1974: 133-153; 1975: 295-307, 321, 333-334; 1977: 111-128. BASANTA REYES, 2000: 46-47, 131, 141-142, 226.

${ }^{4}$ Quenta de fábrica de la yglesia parrochial de San Ginés y San Luis [...], 1736, ff. 91v-97r, Archivo de la parroquia de San Ginés, Madrid (APSG).

5 Óleo sobre lienzo. 232,1 × 166,2 cm. Museo de Arte de Ponce, The Luis A. Ferré Foundation Inc., Puerto Rico, inv. 60.0131. PALOMINo (1724: 488) y Ponz (1776: 249) vieron la pintura en San Luis (sobre la puerta de acceso del lado del evangelio), para donde debió de ser realizada probablemente por encargo del caballero de Santiago que aparece en el primer término del cuadro, junto al Rey, y que sería un feligrés de la parroquia. Antes de 1936 habría cambiado de emplazamiento, aunque su primer paradero conocido posterior fue el Museo del Carnegie Institute (Pittsburgh, EEUU, 1955), pasando, finalmente, en 1960 al Museo de Ponce. Esta obra, la más significativa del catálogo de Ruiz González, se considera precedente iconográfico inmediato de La adoración de la Sagrada Forma de Gorkum (1690) pintada por Claudio Coello (1642-1693) para la sacristía de El Escorial. Véase, sobre todo, SÁNCHEZ CANTÓN, 1943: 400 (dio por perdida la pintura en el incendio de San Luis). GAYA Nuño, 1958: 293, núm. 2527. Held, TAYLOR Y CARDER, 1984: 268-271. López SÁnChez, 2007: 39, 135-138. PÉrez SÁnCheZ, 2010: 324-325. www.museoarteponce.org (consultado en 30-IV-2013).

${ }^{6}$ Libro donde se escriven las cuentas de [...] la ffabrica de la Yglesia Parrochial de $S^{n}$ Xines y San Luis Su anexo que enpieça desde primero de Henero de 1654 [1654-1686], f. 56r, APSG. En septiembre de 1689, se pagó al dorador José de Moya el dorado y estofado de la imagen, renovado con motivo de la próxima reapertura del templo, el 19 de agosto de ese año. Libro de Quentas de la Yg. ${ }^{a}$ Parrochial de S. Gines i S. Luis su Anexo. Año de 1689, f. 143v, APSG.

7 García MenÉndez, 2012: 2949.
}

Arch. esp. arte, LXXXVII, 348, OCTUBRE-DICIEMBRE 2014, 365-382 ISSN: 0004-0428, eISSN: 1988-8511, doi: 10.3989/aearte.2014.23 


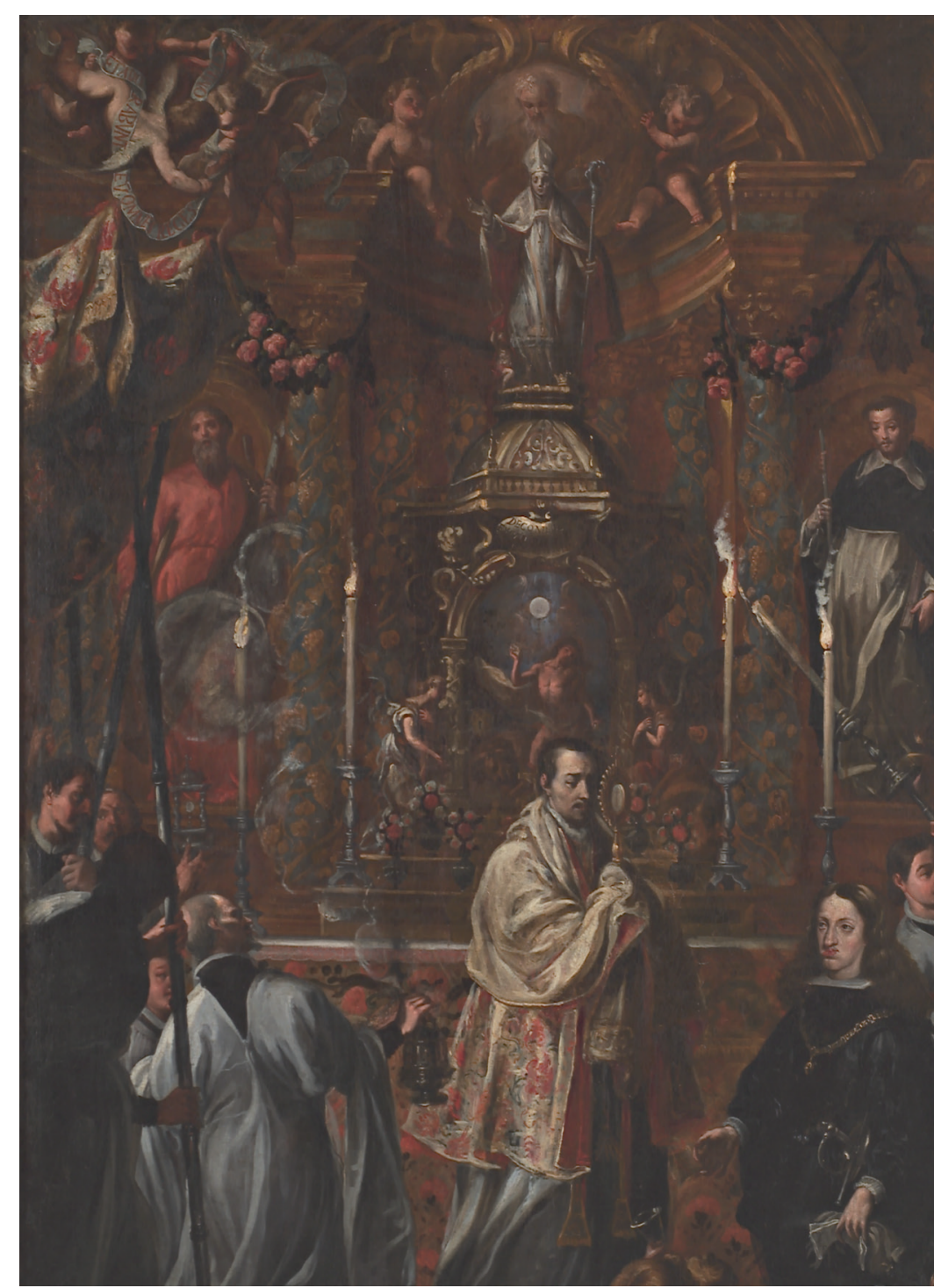

Fig. 3. Pedro Ruiz

González, Carlos II ante la Sagrada Forma, 1683. Museo de Arte de Ponce (Puerto Rico).

mo a la feligresía, pues Villanueva, era ya por entonces uno de los más acreditados arquitectos de retablos de Madrid y directo heredero del estilo de José Benito de Churriguera (1665-1725).

En efecto, al estudiar la producción retablística de Juan de Villanueva ${ }^{8}$, hemos comprobado que las aportaciones de Churriguera fueron su referencia fundamental, y quizá esta fuerte impronta pudiera haberse debido a un trabajo del asturiano como oficial, colaborador, o incluso acaso discípulo, en el taller de José Benito, en los primeros años de Villanueva en Madrid, a comienzos del siglo XVIII; habida cuenta, además, de la conocida amistad que el propio Chu-

\footnotetext{
${ }^{8}$ La biografía y catálogo de Juan de Villanueva sobre todo en GARCíA MENÉndez 2009a; y 2010a.
} 
rriguera y Pedro Alonso de los Ríos (1641-1702), maestro de Villanueva en la Corte, compartieron.

Por ello y por la significación de la clientela que contrató retablos con Juan de Villanueva (Real Consejo de Órdenes Militares, principales casas religiosas de Madrid, catedral de Oviedo, algunos aristócratas), se le puede situar entre los más destacados ensambladores del tercio central del siglo XVIII en Madrid, y considerarle, asimismo, epígono de la retablística castiza y rococó que había tenido su punto culminante en el gran José Benito, y del que este altar de San Luis era también ejemplo conspicuo.

Así pues, Juan de Villanueva estaba en condiciones de proporcionar a su parroquia un nuevo retablo, moderno, monumental y espectacular, similar a los que a lo largo de las primeras décadas de la centuria habían proliferado en numerosos templos y capillas de la Corte de mano del propio Churriguera y de sus discípulos y seguidores. Y esto era sin duda lo que quería la comunidad parroquial, pues antes de firmar el contrato de obra se informó del "coste, modo y forma de otros [retablos] de igual calidad que el que se intentaba poner, y expezialmente del que está puesto en el altar mayor de la yglesia de San Phelipe el Real desta corte, por ser, a corta diferencia, las mismas medidas de ancho y alto que las de dicha yglesia de San Luis"".

Este retablo mayor del templo conventual de los agustinos calzados de San Felipe el Real (desaparecido en $1838^{10}$ ) fue obra del ensamblador guipuzcoano Miguel de Irazusta (1665-1743), realizada entre $c a$. $1718-1723^{11}$, y debió de ser una máquina de gran empaque, como lo demuestran sus dimensiones (similares a las del de San Luis, para el que hemos calculado unos $14 \mathrm{~m}$ de altura, como se verá), su amplio programa iconográfico, integrado por trece estatuas debidas a los escultores Juan de Villanueva y Pablo González Velázquez (1664-1727) ${ }^{12}$, y el que tuviera "mucho coste"13. Constituiría, además, un ejemplo de la retablística postchurrigueresca, como lo prueba el hecho de que Ponz lo describiera como "uno de los más infelices partos de este siglo", testimonio "del miserable estado" a que había llegado en el tiempo de su fábrica la arquitectura española ${ }^{14}$. Y respondería probablemente al tipo de retablo-exedra muy utilizado por Irazusta y, en general, por los tracistas y ensambladores de los dos primeros tercios del XVIII, y tal vez con una ornamentación rococó.

Así pues, quizá con la sugerencia de este referente, Juan de Villanueva, que conocía de primera mano la obra de San Felipe por haber intervenido en ella (aunque únicamente en la estatuaria), se comprometió, el 18 de febrero de 1734, a "hacer, poner y colocar sentado en toda forma" y "en blanco" el retablo mayor de San Luis, según la traza que él mismo había diseñado, y a tallar para su adorno "quince efigies de diferentes santos, ynclusos los quatro doctores, y ángeles y virtudes, y en medio el santo titular", todas de cuerpo entero, así como "una medalla de medio relieve de la ystoria del Santo". Por este amplísimo trabajo cobraría 85.000 reales de

9 Quenta de 1736, ff. 91v-97r, APSG.

10 Amador de los Ríos y Rada y Delgado, 1863: 16.

11 Astiazarain, 1997: 56-57. Su hechura comenzaría después de que en 1718 se incendiara el primitivo altar de madera del templo. Y nos consta que en febrero de 1721 ya se estaban haciendo pagos a su artífice. En enero de 1723 se libraron las últimas cantidades del ajuste de la arquitectura y se empezó a gestionar su dorado, por lo que esa será la fecha de finalización del retablo. Libro de las consultas de este Real convento de San Phelipe de esta corte. Comienza en 10 de agosto de 1694, Archivo Histórico Nacional, Madrid (AHN), Clero secular-regular, libro 6.844, f. 78rv, y Libro de los mandatos [...] de San Phelipe de Madrid [...]. Comenzose [...] en último de mayo de 1631, AHN, Clero secular-regular, libro 6.849, f. s/núm.

12 CeÁn Bermúdez, 1800, II: 226 y V: 255.

13 Asimismo, su dorado ascendió a la elevadísima suma de 90.000 reales. AHN, Clero secular-regular, libro 6.844, f. $78 r v$.

14 PONZ, 1776: 294.

Arch. esp. arte, LXXXVII, 348, OCTUBRE-DICIEMBRE 2014, 365-382

ISSN: 0004-0428, eISSN: 1988-8511, doi: 10.3989/aearte.2014.23 
vellón, quedando también "a su beneficio" la imagen de San Luis que se veneraba en el antiguo altar y que él sustituiría con otra realizada en su taller ${ }^{15}$.

Las labores de talla y ensamblaje de las piezas del retablo debieron de prolongarse bastante tiempo. Si bien en octubre de 1734, ocho meses después de la firma del convenio, se pagó a un maestro carpintero el desmantelamiento del viejo altar mayor y la preparación del asiento del nuevo ${ }^{16}$, aún en las cuentas de 1736 se indicaba que en ese momento "el dicho retablo se hallava echo, puesto y colocado más de la mitad"17. Asimismo, en un inventario de los bienes de la familia Villanueva compuesto tras la muerte de la primera esposa del escultor se registró, el 19 de abril de 1736, como parte de los "trastos del obrador" del artista, la madera que hubiese "en el rrettablo que se está ejecutando en la Yglesia de San Luis Obispo"18. El propio Juan declaró que "en la obra del Retablo que actualmente está ejecutando en la Yglesia de San Luis Obispo" se le debían 10.176 reales de los 38.500 que hasta entonces había gastado en el trabajo ${ }^{19}$.

Parece claro, pues, que la empresa todavía no había llegado a su fin en 1736, y seguramente en buena parte por la lentitud de la financiación, ya que el altar se costeó gracias a los caudales procedentes de las rentas de la propia parroquia y a las suscripciones y limosnas entregadas por una concurrencia muy generosa de devotos, "así parrochianos como de fuera" 20 , con lo que dependía en buena medida de algo tan aleatorio e irregular como la buena voluntad de los feligreses.

Aunque no nos consta la fecha de terminación de la obra, los pagos por la dilatada intervención de Juan de Villanueva en el gran retablo de San Luis concluirían finalmente el 20 de noviembre de 1740, más de seis años después de que se acordara su hechura (en enero de 1734). El escultor dio entonces el último recibo a la fábrica parroquial por su trabajo, con lo que se certificaba así el término de la arquitectura y decoración del altar, cuyo coste había alcanzado finalmente 90.500 reales, con las "mejoras y demasías" que Villanueva había realizado.

El dorado, a pleno oro, se concertó en mayo de 1740 con los doradores Gabriel Vidal († $c a$. 1747), Manuel López de Gobeo y Francisco Pérez ${ }^{21}$. Igual que había ocurrido con la arquitectura, el coste fue altísimo, al tratarse de una máquina de notable magnitud y complejidad, elevándose hasta 97.360 reales $^{22}$. Vidal y Gobeo eran también feligreses de San Luis, además de amigos y vecinos de Villanueva ${ }^{23}$, y el primero había renovado ya en 1731 el dorado de la capa y mitra de la antigua efigie de San Luis Obispo ${ }^{24}$.

15 Todo en Quenta de 1736, ff. 91v-97r, APSG.

16 Quenta de 1736, f. 181v, APSG.

17 Quenta de 1736, ff. 91v-97r, APSG.

18 Archivo Histórico de Protocolos, Madrid (AHPM), protocolo 16.965, ff. 13v-14r. La cursiva en el texto es nuestra. El inventario lo dio a conocer Agulló, 1982: s/núm.

19 Mismo documento de la nota anterior, f. 16. La cursiva también es nuestra.

${ }^{20}$ Quenta de 1736, ff. 91v-97r, APSG.

21 Cuenta de 1741, ff. 240r-242v, APSG.

22 Los maestros doradores dieron los recibos correspondientes en octubre de 1741, aunque quedarían pendientes algunas cantidades, pues en 1747 Gabriel Vidal hizo constar en una declaración de pobreza que se le debía algo más de 1000 reales de su intervención en el dorado del retablo de San Luis. AHPM, protocolo 16.403, f. 41.

${ }^{23}$ Otro de los trabajos más destacados de Vidal fue el dorado, en 1723, del retablo mayor de la iglesia de San Sebastián de Madrid, de José Benito de Churriguera, lo cual revela que debía de ser un artífice de notable valía, habitual en el círculo artístico en que también se movía Villanueva. López de Gobeo, por su parte, aparece como testigo en un poder para testar del dorador Vidal de 1720, por lo que debían de trabajar conjuntamente con cierta asiduidad y eran, desde luego, amigos. Para estas y otras noticias documentales sobre Vidal y Gobeo, GARCíA MenÉndeZ, 2012: 29432955.

${ }^{24}$ Cuentas de la fábrica de San Ginés y San Luis. Año 1731, ff. 118v-119r, APSG. García Menéndez, 2012: 2950.

Arch. esp. arte, LXXXVII, 348, OCTUBRE-DICIEMBRE 2014, 365-382 ISSN: 0004-0428, eISSN: 1988-8511, doi: 10.3989/aearte.2014.23 


\section{Análisis de la estructura arquitectónica: formas y fuentes de inspiración}

Afortunadamente, nuestras referencias sobre el retablo de San Luis, a pesar de tratarse de un conjunto ya desaparecido, no se agotan con los datos documentales aquí presentados. La localización en el Archivo Moreno de una fotografía antigua en blanco y negro que reproduce el presbiterio del desaparecido templo ${ }^{25}$, y que ha pasado inadvertida para otros investigadores del barroco madrileño, nos ha brindado la oportunidad de analizar detenidamente la estructura del altar, su dependencia de los modelos churriguerescos y su programa iconográfico (fig. 4). Y, sobre todo, nos ha proporcionado un valioso testimonio para el estudio de la obra del escultor Juan de Villanueva, pues de sus retablos documentados se conservan hoy únicamente los colaterales de las Calatravas de Madrid (1727) y los de la catedral de Oviedo (1739) ${ }^{26}$.

Sabemos así que el retablo mayor de San Luis Obispo, del tipo habitualmente denominado de exedra u hornacina, alzaba sobre un zócalo de piedra cubierto de placas lisas de mármol (que no corrió por cuenta de Juan de Villanueva), y constaba de un alto banco, un cuerpo principal tetrástilo de cinco calles y sin división en pisos, y un ático en forma de cuarto de esfera. Toda esta arquitectura creaba, con el movimiento de entrantes y salientes de su planta, una impresión de concavidad en el muro del presbiterio que, como muestran las fotografías del templo tomadas antes de su demolición (fig. 5) 27 $^{27}$ era recto.

Utilizando como referencia el plano del templo de San Luis levantado por el arqueólogo Vicente Ruiz Argilés después de la Guerra Civil y su correspondiente escala ${ }^{28}$, podemos apuntar de forma aproximada las dimensiones del retablo de Juan de Villanueva: el ancho del muro del presbiterio, coincidente con el del altar, era de $8 \mathrm{~m}$, y aplicando el dato a la fotografía del Archivo Moreno y calculando la proporción correspondiente, podemos obtener una altura de unos 14 $\mathrm{m}$ para el retablo y para el paramento del testero que aquel cubría por completo.

De la estructura del altar merecen ser destacados algunos elementos: las columnas de orden salomónico gigante, con sus espiras giradas hacia afuera en la calle central, para acentuar una sensación de torbellino ascendente en esta parte del altar, y hacia adentro las exteriores, cerrando así la composición de todo el conjunto y dirigiendo la mirada hacia el cuerpo de gloria; las ménsulas de esos soportes, potentes, plásticas y de gran vuelo; y las falsas hornacinas fingidas en las calles extremas que, con las esculturas apoyadas en repisas bajo ellas, cubrían la ausencia de vanos y añadían un componente de desequilibrio y contraste por ubicarse, además, a un nivel más bajo que los nichos-exedra de las otras calles.

La calle central se concibió como protagonista del conjunto, pues todo el énfasis escenográfico se concentró en ella, además de como elemento de articulación del retablo. Estaba unificada en todo su desarrollo vertical, con sus hornacinas y adornos de talla enlazados, transmitiendo así un impulso ascendente que comenzaba en el gran tabernáculo alojado en un hueco con transparente $^{29}$. El cuerpo de gloria, con la efigie del santo patrono del templo, contaba con varios niveles de profundidad, para acentuar la concavidad fingida de la cabecera, y la impresión visual de

25 Archivo Moreno, IPCE, Ministerio de Educación, Cultura y Deporte, inv. 36343_B, placa de vidrio al gelatinobromuro, $18 \times 24 \mathrm{~cm}$. La fotografía no está fechada, pero el conjunto del Archivo Moreno lo conforman las imágenes tomadas por Mariano Moreno García (1865-1925) y su hijo, Vicente Moreno Díaz (1894-1954), entre 1893 y 1954. En este caso sería, evidentemente, anterior a marzo de 1936.

${ }^{26}$ Sobre estos retablos, sobre todo, Bonet CoRrea, 1962: 21-49. RAmallo, 1985: 104-108, 419-442. GonZÁlez SANTOS, 1998: 57-58 y 84-86. GARCíA MENÉNDEZ, 2007: 57-68; 2009a, II: 561-592; 2010a, pp. 46-55.

27 Al día siguiente del incendio, el 14 de marzo de 1936, el fotógrafo madrileño Luis Ramón Marín (1884-1944) tomó una imagen del interior del templo de San Luis (fig. 5), en la que se ve la cabecera ya sin el retablo de Villanueva (publicada en AA.VV, 2007: 362). Otra vista más en RuIZ ARGILÉs, 1953: lám. III.

${ }^{28}$ RuIZ ArgiLÉs, 1953: 42.

${ }^{29}$ La gradería que se ve en la fotografía parece añadido posterior.

Arch. esp. arte, LXXXVII, 348, OCTUBRE-DICIEMBRE 2014, 365-382

ISSN: 0004-0428, eISSN: 1988-8511, doi: 10.3989/aearte.2014.23 


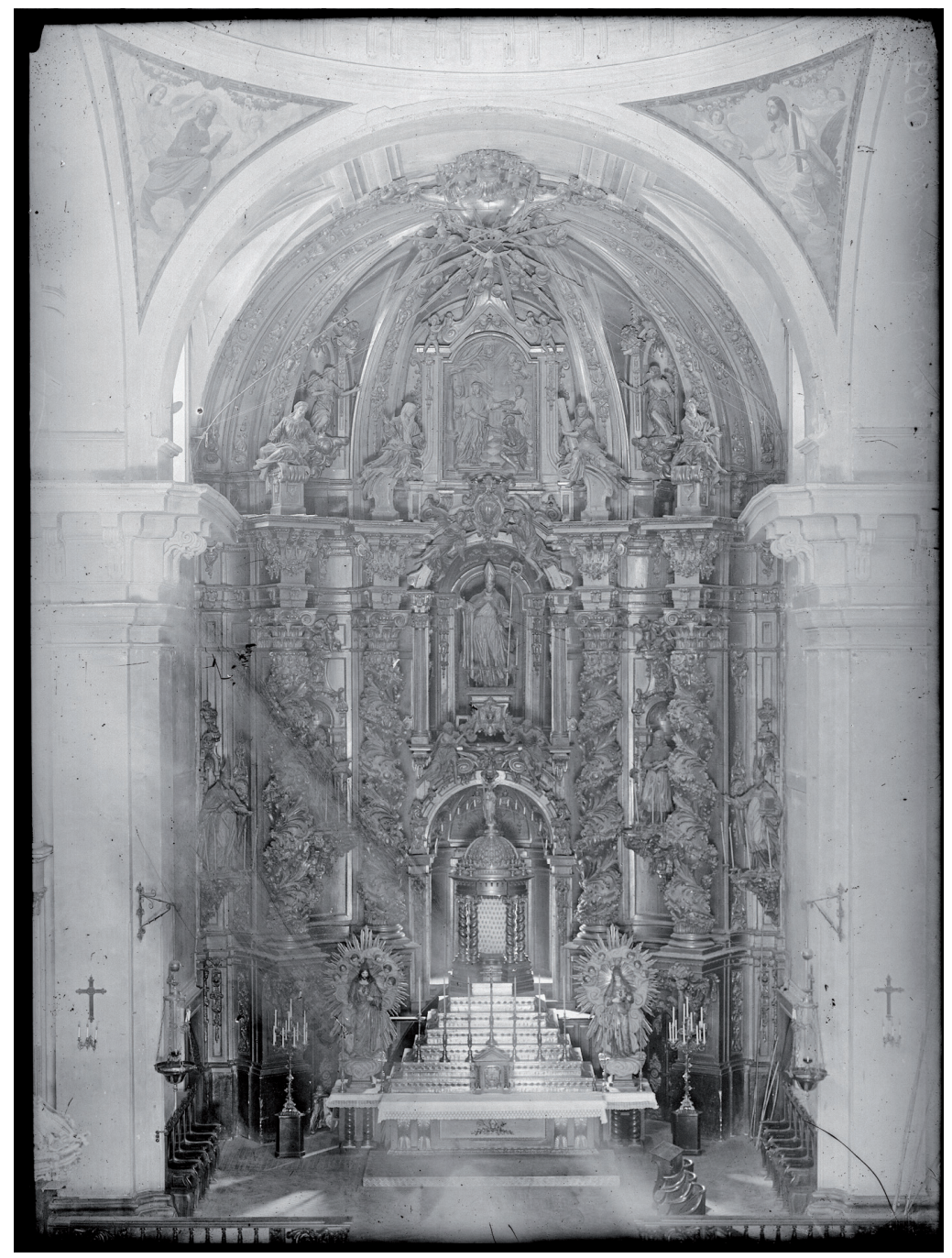

Fig. 4. Retablo mayor de la iglesia de San Luis Obispo, Archivo Moreno, IPCE, Ministerio de Educación, Cultura y Deporte, inv. 36343_B.

una estructura en fuga. Sobre su arco exterior dos ángeles sostenían y elevaban un escudo con las armas del antiguo reino de Sicilia (por haber sido san Luis primogénito de Carlos II de Sicilia), que rompía y curvaba el entablamento, muy moldurado y que se hacía eco del agitado movimiento de la planta y ocupaba en su desarrollo parte del ático.

A través de algunas vistas fotográficas del interior del templo tomadas tras la desaparición del retablo de Villanueva, como la de Luis Ramón Marín que aquí se incluye, se puede comprobar que los dos nichos principales, los del tabernáculo y el santo titular, se adaptaban a sendos huecos abiertos en el propio testero de la iglesia (fig. 5). Al menos uno de ellos, el del manifestador, se habría realizado ya para el retablo anterior que, como se ve en el citado lienzo de Ruiz González, había contado igualmente con un ostensorio monumental en una hornacina a la misma altura. Villanueva acomodó su diseño, por tanto, a la presencia de ese elemento arquitectónico. Esta hornacina inferior tenía, como muestran esas fotografías, una ventana, aprovechada, al menos por Juan de Villanueva, para disponer un transparente en el espacio del manifestador, y así en la fotografía del Archivo Moreno se aprecia cómo, efectivamente, este hueco recibe luz desde atrás. 


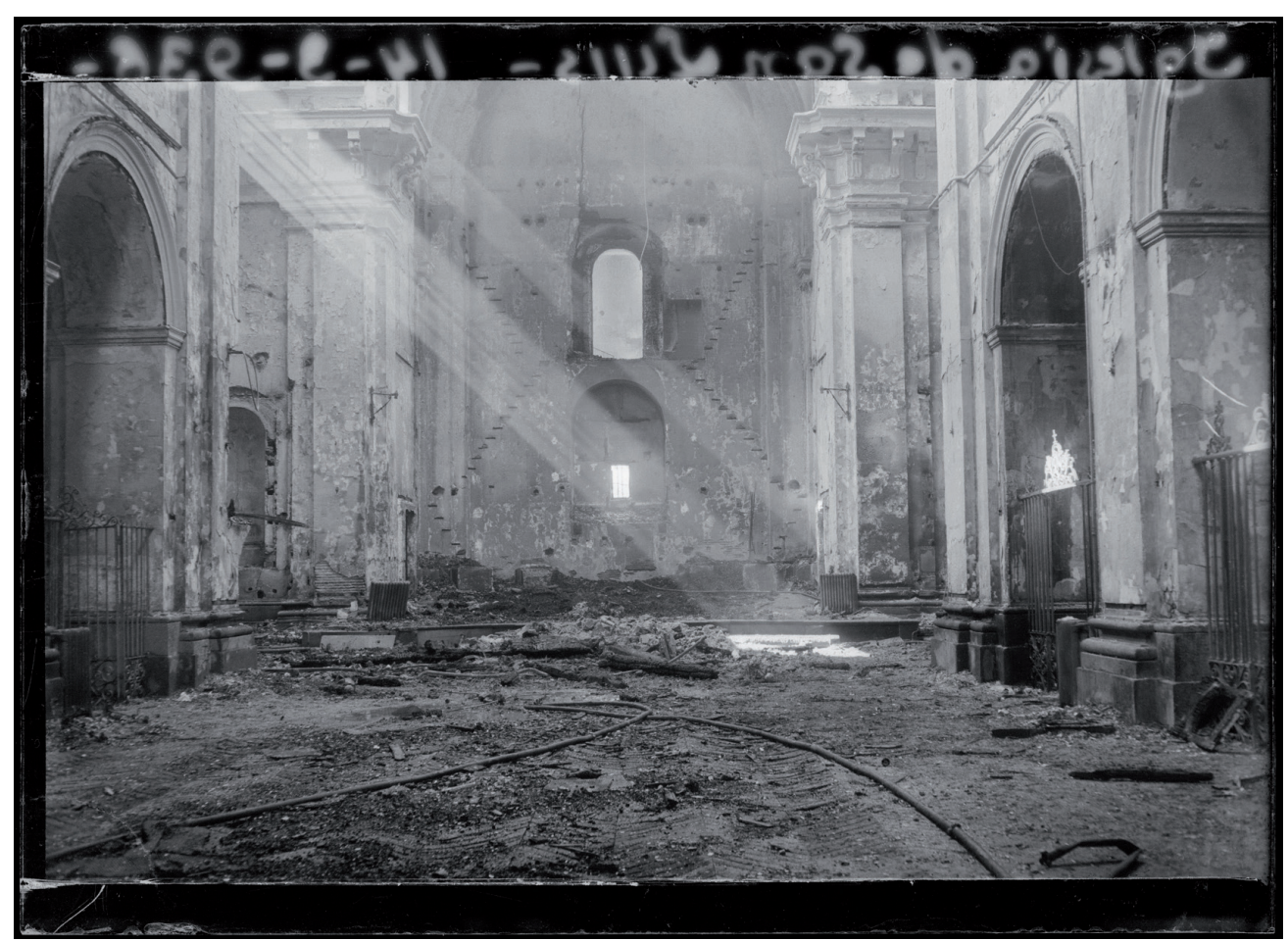

Fig. 5. Luis Ramón Marín, Vista del interior de la iglesia de San Luis, de Madrid, 1936. Fotografía del Archivo Marín cedida por Fundación Telefónica. (C) Marín, Vegap, Madrid 2013.

Por su lado, el superior era un nicho con dos niveles de profundidad, al modo de un camarín, que Villanueva incorporó asimismo a su estructura, y que probablemente fuera también un elemento preexistente que adaptó a su proyecto. Como se ve en la fotografía de Marín, a él se podía acceder por medio de dos escaleras, de las que partían otros dos tramos de escalones para alcanzar el ático del retablo, al que se llegaría a través de alguna trampilla, como la que se aprecia en la fotografía del Archivo Moreno en la parte derecha del cascarón. Al exterior, una reja, cegada al menos justo antes de la demolición del edificio, debía de cerrar una ventana ${ }^{30}$, que Juan de Villanueva no utilizó para dar luz al cuerpo de gloria del retablo, pero que tal vez sí sirvió en el anterior altar o simplemente se abrió al construir el muro como elemento de iluminación del templo, que quedaría luego oculto por el retablo monumental que tapó el presbiterio.

Por su parte, el friso estaba recorrido por mutilos dobles, iguales que los del cuerpo de la iglesia (elemento muy característico del barroco arquitectónico madrileño del siglo XVII en que se había construido la mayor parte del edificio) pero de ritmo más apretado. Y los cubos correspondientes a las columnas actuaban como amplias repisas para colocar, en el ático, cuatro figuras de virtudes.

El ático, de gran desarrollo, describía un cuarto de esfera, cubriendo parte de la bóveda del presbiterio. Su planta seguía un esquema similar al del cuerpo principal y el centro lo ocupaba una escena en mediorrelieve. Encima, dos aletones avolutados y una pareja de angelitos que

${ }^{30}$ Hemos visto una fotografía del estado de la fachada posterior del edificio en 1942 en http://www.flickr.com/ photos/nicolas1056/3950206057/(consultada el 27 de septiembre de 2013).

Arch. esp. arte, LXXXVII, 348, OCTUBRE-DICIEMBRE 2014, 365-382

ISSN: 0004-0428, eISSN: 1988-8511, doi: 10.3989/aearte.2014.23 
señalaban hacia lo alto servían de transición hacia un rompimiento de gloria y un desbordante tarjetón que abrochaba la clave del ático y se desparramaba sobre el guardapolvo y la cubierta del presbiterio. Finalmente, en los gajos laterales de la semicúpula de remate, sendas hornacinas acogían figuras de ángeles arrodillados, adorando a san Luis y a la Gloria Celestial.

En definitiva, este altar de San Luis Obispo, el más espectacular y monumental del catálogo de Villanueva, tenía una arquitectura fluida, dinámica y vibrante, en plena consonancia con el estilo del barroco madrileño contemporáneo de los seguidores de Churriguera. De hecho puede advertirse el parentesco que presentaba esta arquitectura, en planta y alzado, con el desaparecido retablo del templo de la Merced Calzada de Madrid (h. 1700), y con el mayor de la iglesia del Salvador de Leganés (1701-1707), ambos obras de Churriguera ${ }^{31}$. Y seguramente tenía también este retablo de San Luis gran similitud con el mayor de San Felipe el Real, de Irazusta, que, recordemos, era uno de los ejemplos que se había querido emular en San Luis, y que bien pudo haber tomado asimismo como modelo a Churriguera.

Además, Juan de Villanueva debió de recurrir para su trabajo como diseñador de retablos a una guía compartida con el propio José Benito: la Perspectiva pictorum et architectorum (Roma, 16931700, 2 vols.), del pintor y escenógrafo italiano Andrea Pozzo (1642-1709), que el asturiano tenía en su biblioteca en 1735, en el mismo momento en que se estaba fabricando este retablo ${ }^{32}$, y cuyas láminas proporcionaron a numerosos artistas barrocos contemporáneos múltiples ejemplos de cómo construir arquitecturas en marcada fuga, como bien prueba el tipo de composición de este altar de San Luis, en el que todos los elementos y recursos conducen en una progresión pautada por entrantes y salientes hacia un sólo punto focal, la hornacina del santo patrono de la feligresía.

Y así también en este retablo de San Luis las hojas de palma de pétalos deshilachados dispuestas en el cuello de las espiras de las columnas principales son un elemento novedoso, apenas utilizado contemporáneamente en Madrid, y que remite a modelos suministrados por el Padre Pozzo (fig. 6) o Juan Caramuel (1606-1682) 33; al igual que la base de esos soportes, que semejaba un cogollo vegetal del que naciera la exuberante ornamentación y que parece tomado de las láminas de este último tratadista mencionado (fig. 7) ${ }^{34}$.

Por lo que respecta a la decoración desparramada por las superficies del retablo de San Luis, el repertorio es amplísimo, de una gran riqueza y variedad. Y en Juan de Villanueva toda esta ornamentación tiene una clara filiación rococó (patente en la delicadeza, naturalismo y pictoricismo de los ornatos de sus retablos conocidos), además de una cercanía a los temas decorativos empleados por Churriguera, Pedro de Ribera (1681-1742) o Narciso Tomé (1690-1742). Pero nos interesa resaltar, sobre todo, la participación que en el diseño de estos adornos hubo de tener Diego de Villanueva (Madrid, 1713-1774), hijo y discípulo de nuestro escultor y colaborador en el obrador familiar como tracista de retablos hasta $c a$. 1745, pues pueden verse muchas similitudes con algunas de las láminas del Libro de diferentes pensamientos, compuesto por Diego hacia $1754^{35}$.

${ }^{31}$ La similitud con el retablo de Leganés la apreció ya TAMAYo, 1946: 123-124. El desaparecido retablo de la Merced se conoce por un proyecto del propio Churriguera, conservado en el Gabinete de Dibujos de la Academia de San Fernando, inv. D/2385. El de Leganés se conserva in situ. RodríGuez de Ceballos, 1971: 22-23 y láms. 10 y 13.

32 AHPM, protocolo 16.965, ff. 14rv y 33r-35r. GARCíA MENÉNDEZ, 2010b: 222; 2011: 318.

33 Así, en la figura LXV del tratado de Pozzo (1700, vol. II) aparece ese mismo tipo de columnas con hojas en las gargantas (GARCía MenÉndeZ, 2010b: 223). Y se pueden ver también motivos similares en Caramuel (1678, III, parte II, lám. LIX).

34 También en la ilustración de Caramuel citada. Aunque este libro no consta en el único inventario conocido de la biblioteca de Juan de Villanueva (1735), fue una fuente de enorme influencia en la arquitectura barroca española y nos parece perfectamente posible que también el asturiano lo hubiera manejado, como parece demostrar este caso.

35 Villanueva, 1979: láms. 2, 4, 3, 6, 11, 12, 14, 15, 16 y 17. Sobre la participación de Diego de Villanueva en el taller familiar, GARCíA MENÉNDEZ, 2011: 312-323.

Arch. esp. arte, LXXXVII, 348, OCTUBRE-DICIEMBRE 2014, 365-382 ISSN: 0004-0428, eISSN: 1988-8511, doi: 10.3989/aearte.2014.23 


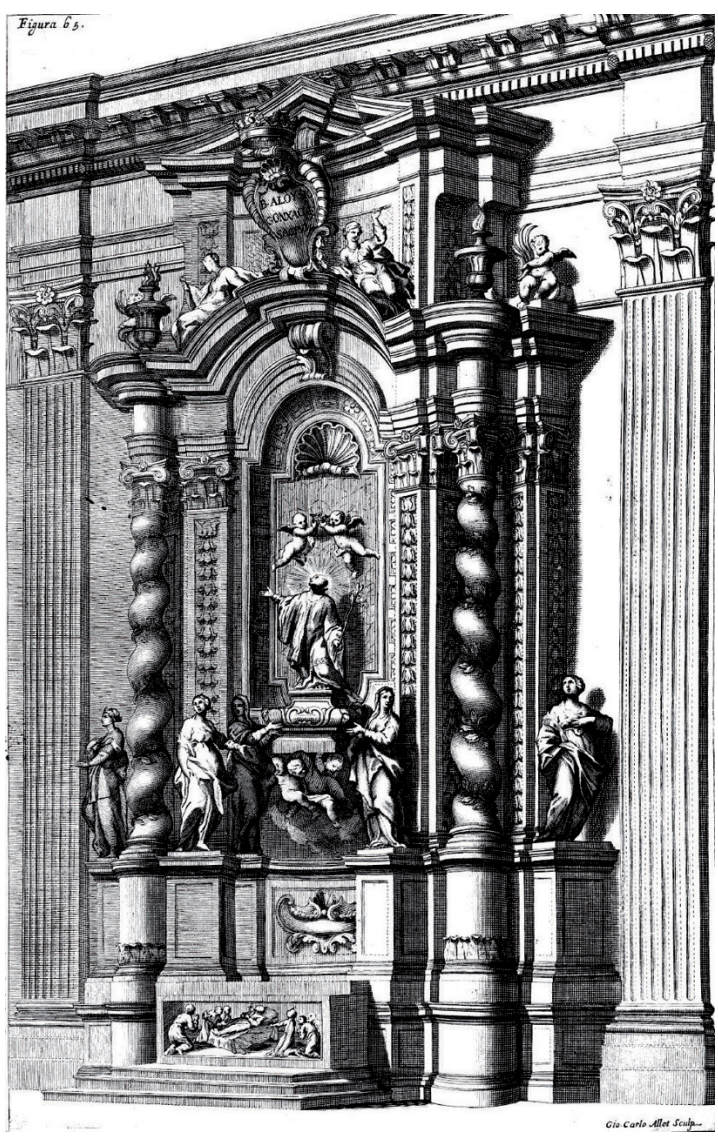

Fig. 6. Giovanni Carlo Allet, Figura 65, en Pozzo, Perspectiva Pictorum et Architectorum, Roma, 1700, vol. II.

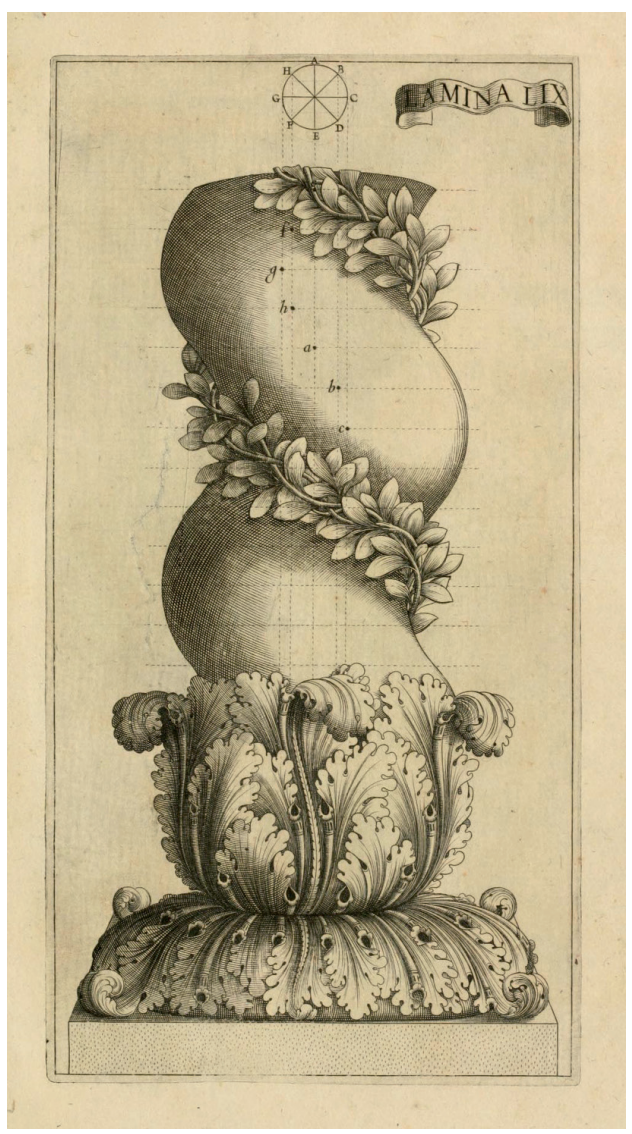

Fig. 7. Lámina LIX de J. Caramuel, Architectura civil recta y obliqua, Vigevano, 1678 , tomo III, parte II.

\section{Las esculturas}

El programa iconográfico del retablo incluía las siguientes piezas de madera policromada: los cuatro Doctores y Padres de la Iglesia Latina y el patrono de la feligresía en el cuerpo principal; alegorías de las cuatro virtudes cardinales ante el basamento del ático; un relieve con el santo atendiendo a los pobres, en el centro de aquel; y dos ángeles en los nichos a los lados de este cuadro; así como una gloria bajo el tarjetón de broche y otras tres parejas de querubines, de pequeño y mediano tamaño, que pueden considerarse más elementos decorativos que figuras independientes.

De entre esas imágenes la principal era la del titular, San Luis Obispo, que ocupaba el nicho central del conjunto, concebido como punto focal del altar (fig. 8). La iconografía elegida por Villanueva para la representación del santo lo mostraba en pie, realizando un gesto de bendición, imberbe (para señalar su juventud, pues falleció a los veintitrés años, en 1297), vestido con hábito (que sería el de su orden, la franciscana), mitra, capa pluvial y báculo, por su condición de obispo de Tolosa (Toulouse, Francia), y como complemento, en la peana se dispuso lo que pare- 


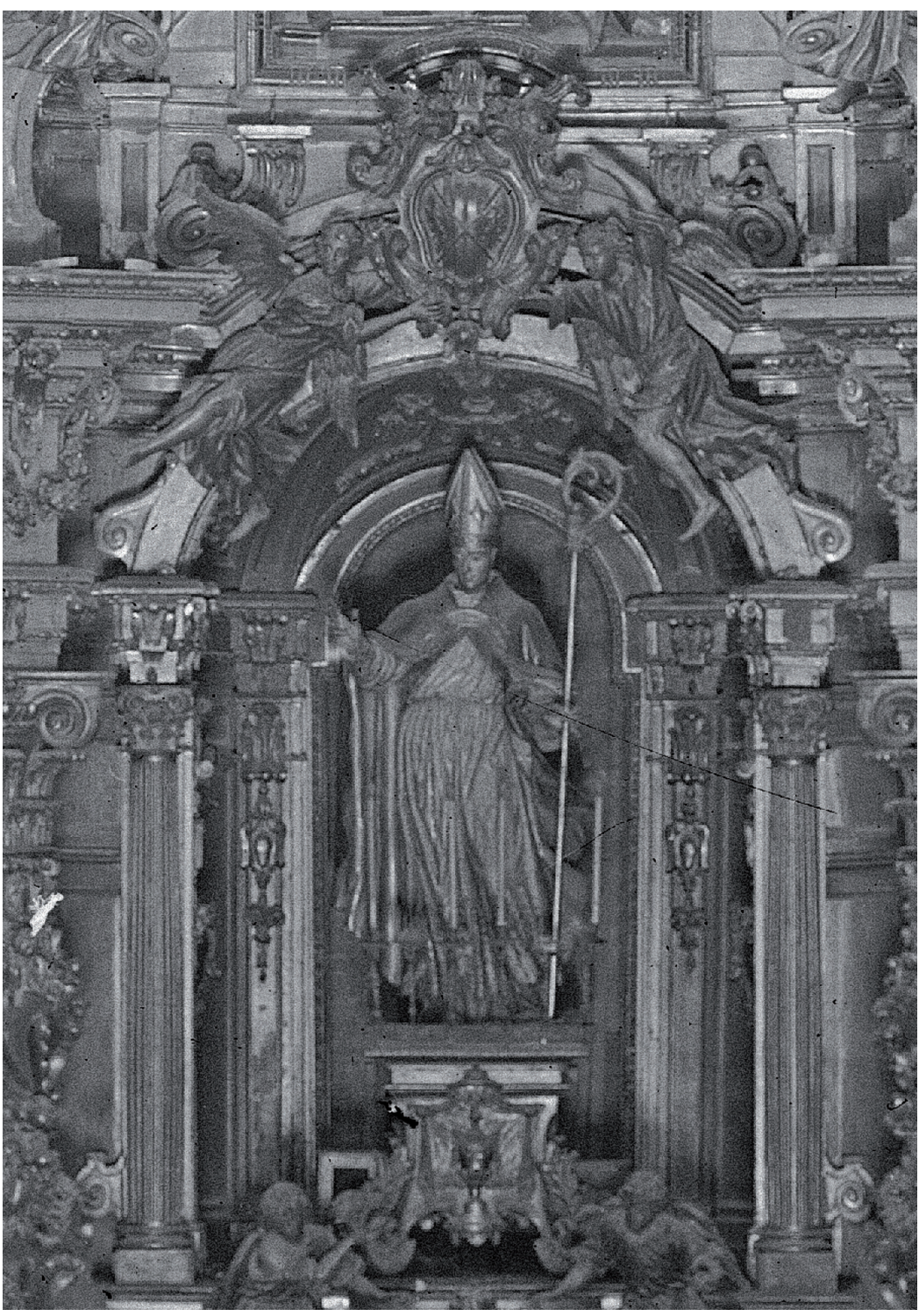

Fig. 8. Detalle de la figura de San Luis Obispo.

ce una corona real, la del reino de Sicilia que al santo le correspondía por herencia y que cedió a su hermano, símbolo por tanto de su renuncia a los poderes terrenales ${ }^{36}$. En todo ello siguió el escultor asturiano el modelo de la figura del anterior retablo.

Se aprecian también varios de los rasgos estilísticos y compositivos que hemos identificado como habituales en la producción de madurez de Villanueva, que ha de encuadrarse en el barroco dieciochista, en un estilo de transición entre el casticismo y un temprano academicismo o clasicismo, y en un tipo de naturalismo sensible: perfil ahusado, cabeza algo ladeada y mirada

\footnotetext{
36 RÉAU, 1997b: 280-283.
} 
dirigida hacia abajo; brazos abiertos en un expresivo gesto de bendición; rostro de delicadas facciones y gesto reconcentrado y afable, y vestimentas de plegados abundantes, menudos y nerviosos. Y como elemento identificativo de la mano de Juan de Villanueva, en uno de los brazos las telas se enroscan recordando a los pétalos de una rosa en flor ${ }^{37}$.

Es interesante poner en relación esta imagen con el San Luis que el escultor madrileño Pablo González Velázquez labró en piedra de Tamajón, en 1720, para la portada principal del propio templo de San Luis Obispo, hoy en el del Carmen (fig. 2) ${ }^{38}$. Pues, aunque hay diferencias en el tratamiento de los ropajes, más sumario en González Velázquez quizá por exigencia del material, si bien de gran calidad; y en el gesto, pese a que el afecto expresado es el mismo, también es posible observar la cercanía entre ambos escultores, estrictamente coetáneos y con una formación similar, y su común asimilación del arte cortesano italiano y francés que, por su temprana muerte en 1727, fue menor en el caso de González Velázquez, un artista de producción aún escasamente conocida, pero clave, como Villanueva, en la transformación artística de la primera mitad del siglo XVIII en Madrid.

Además de la imagen del titular de la parroquia, en el primer cuerpo del retablo se dispusieron figuras de los cuatro Padres de la Iglesia Latina (fig. 9), si bien su inclusión en el conjunto hubo de obedecer únicamente a un interés devocional de la parroquia, pues son complemento extraño en la iconografía de san Luis.

En los intercolumnios de la derecha se encontraban las efigies de San Jerónimo y San Agustín, vestidos, respectivamente, con indumentarias de cardenal y obispo (perdido el báculo de este en la fotografía del Archivo Moreno) y portando como atributos los comunes en la iconografía de los Doctores de la Iglesia, el primero, un libro abierto y una pluma, alusivo en este caso a la Vulgata $^{39}$, y el segundo, una maqueta de iglesia, por haber sido reivindicado por los clérigos regulares agustinianos como fundador de su orden ${ }^{40}$.

En las calles de la izquierda se colocaron las esculturas de San Gregorio y San Ambrosio, el primero con un libro abierto, en referencia a sus numerosas obras teológicas y devocionales y parece que sin la tiara y la cruz pontificia habituales en su iconografía ${ }^{41}$, y el último, con ropas de obispo y una colmena en la mano (perdido también aquí un báculo que parecía sostener en la otra), atributo habitual del santo que remite a un episodio de su vida recogido en la Leyenda Dorada de Santiago de la Vorágine ${ }^{42}$.

Al igual que en el San Luis ya comentado, y como rasgo común con la producción de otros escultores dieciochistas, la composición de las figuras seguía en estos casos un perfil ahusado de comedido movimiento; con ropajes recorridos por arrugas blandas y redondeadas, buscando la diferenciación de calidades textiles y un ritmo sinuoso y agitado; y una expresión de los afectos apoyada en la gestualidad de brazos y poses.

37 GARCía MENÉndez, 2009b: s/núm.

${ }^{38}$ El 5 de junio de 1720 ya estaba concluida y colocada en su lugar de destino, pues en ese momento González Velázquez firmó una carta de pago dando cuenta del cobro de 8.000 reales que se le debían «por razón de las ttres hechuras de Piedra de Tamajón que tiene executtadas, la una de San Luis, de ocho tercias de altto con su mitra y terrazo [es un jarro], y las dos de dos Niños, de la misma piedra, Correspondientes a dicho santto» (Protocolo 15.360, f. 459, AHPM. Quentas [...] desde 1719 hasta 1723, ff. 193v-194r, APSG). Los querubines estaban sobre los aletones de la portada, pero se han perdido. Un grabado con la portada en su emplazamiento original y con las tres figuras de González Velázquez se encuentra en Mesonero Romanos, 1851: 73. Para la escultura, Ceán, 1800, II: 226. UrReA, 1977: 486.

39 RÉAU, 1997b: 142 y147.

40 RÉAU, 1997a: 38.

41 RÉAU, 1997b: 48.

42 RÉAU, 1997a: 37 y 69.

Arch. esp. arte, LXXXVII, 348, oCTUBRE-DICIEMBRE 2014, 365-382

ISSN: 0004-0428, eISSN: 1988-8511, doi: 10.3989/aearte.2014.23 


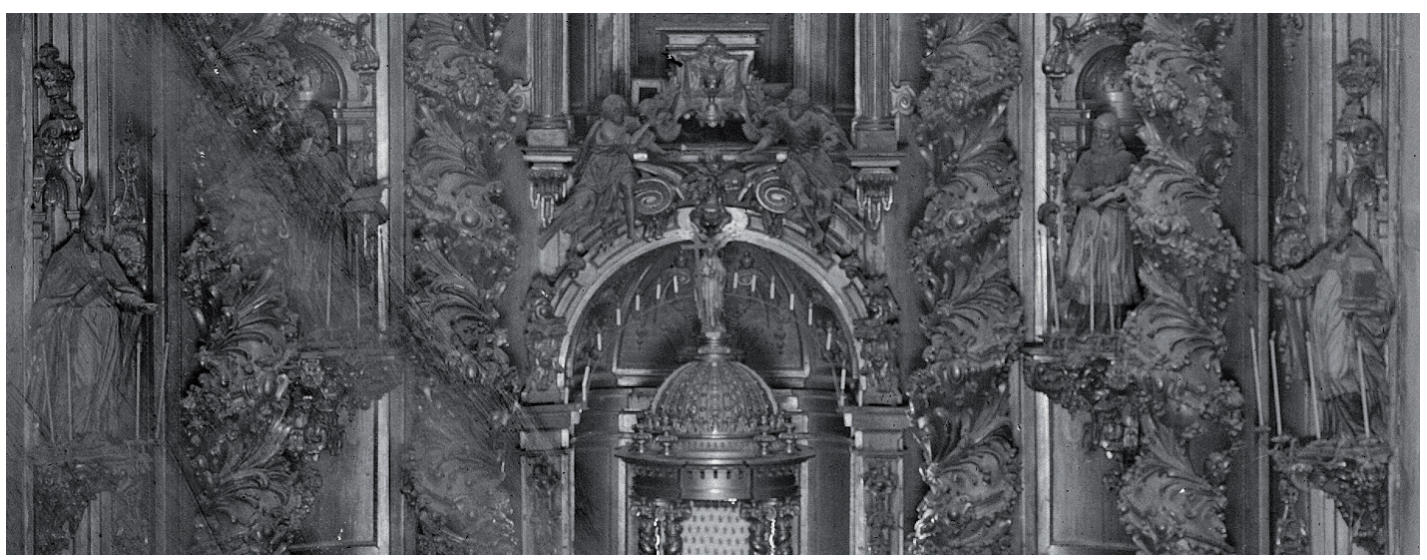

Fig. 9. Detalle de los Padres de la Iglesia Latina.

Aunque no es posible distinguir en nuestro documento visual apenas los rasgos y gestos de los rostros de estas esculturas, sí se puede apuntar que la cabeza del San Jerónimo parece guardar gran similitud con la tallada por Luis Salvador Carmona (1708-1767) en 1741 para la capilla de la hermandad de libreros de Madrid, en la iglesia de San Ginés, como renovación de una escultura anterior del mismo santo, posiblemente obra del escultor asturiano Juan Alonso de Villabrille y Ron (ca. 1663-1732), a cuyos modelos remite claramente Carmona en esa cabeza ${ }^{43}$. Por su lado, la influencia de Villabrille en Villanueva fue consecuencia lógica de la estrecha relación que ambos mantuvieron por compartir patria y profesión ${ }^{44}$.

Todas estas piezas, como el conjunto del retablo, eran de madera policromada, y aunque la fotografía en blanco y negro del Archivo Moreno no nos permite hacer referencia a sus acabados pictóricos, todo apunta a que se siguió la moda cortesana, de colores lisos y planos, sin ningún tipo de floritura ornamental.

El relieve situado en el centro del ático (fig. 10) es obra casi excepcional dentro del catálogo de Juan de Villanueva ${ }^{45}$, pues hasta el momento solo conocemos otro más salido de su mano, $L a$ destrucción de Sagunto, labrado sobre un modelo de Giovan Domenico Olivieri (1708-1762) entre 1752-1760, en altorrelieve y mármol de Badajoz, para una de las sobrepuertas del corredor principal del Palacio Real Nuevo, y que quedó inacabado por la suspensión de los trabajos decorativos del edificio ordenada por Carlos III en $1760^{46}$.

En el caso del altar de San Luis, era una escena tallada en madera, en bajo y mediorrelieve, y representaba al obispo santo de Tolosa acompañado de otro hermano de religión y un acólito realizando una obra de caridad con un hombre anciano, arrodillado y descalzo, que está recibien-

43 Sobre esta escultura PAREdes, 1988: 239. BASANTA, 2000: 159-161, 228 y 335. GARCía MENÉNDEZ, 2013: $135-$ 143.

44 García MenÉndeZ, 2009c: 73-82.

45 Tampoco fue una especialidad en la que se prodigaran otros escultores contemporáneos, quizá, como indica Francisco Portela Sandoval, por la elección más habitual de grandes lienzos para ocupar los huecos de los retablos en vez de cuadros de talla. Portela, 1986: 47-96.

46 Mármol blanco de Badajoz, $84 \times 123 \times 20 \mathrm{~cm}$, Museo Nacional del Prado, inv. E472. Véase, sobre todo, Lorente Junquera, 1954: 58-71. Plaza Santiago, 1975: 181-187. Tárraga Baldó, 1996: 45-67. García Menéndez, 2009a, II: 1013-1036. 


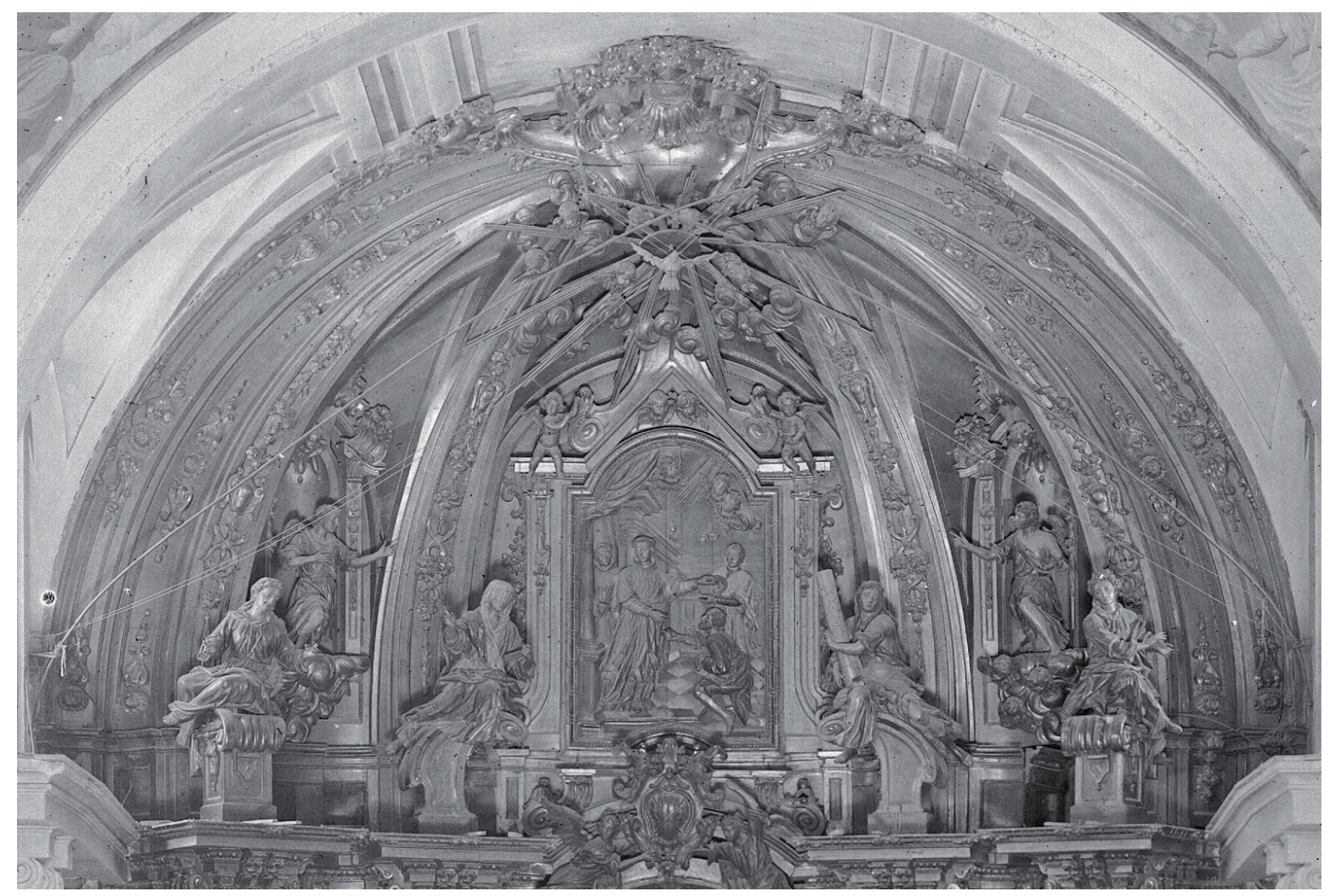

Fig. 10. Detalle de La caridad de San Luis Obispo, virtudes y ángeles del ático del retablo de San Luis.

do algo del protagonista. Este asunto se referirá a alguna de las numerosas anécdotas recogidas en la hagiografía de san Luis de Anjou sobre su atención a enfermos y necesitados ${ }^{47}$.

La iconografía comparte similitudes con muchas referencias pictóricas de santos limosneros y es una temática presente, además, en las representaciones de san Luis Rey (1226-1270), tío abuelo de san Luis de Tolosa ${ }^{48}$, como se muestra en el lienzo San Luis Rey dando limosna a los pobres pintado por Luis Tristán (h. 1585-1624) ca. 1613-1616 para el claustro del convento dominico de San Pedro Mártir de Toledo ${ }^{49}$ y cuyo grupo principal tiene una indudable similitud con la composición de nuestro escultor, por lo que estaremos ante la utilización de alguna fuente común $^{50}$. Y, desde luego, Villanueva recurrió a modelos del siglo XVII, en el cortinaje como modo de enmarcar la historia dentro de un decorado solemne, el escenario arquitectónico clasicista y el ajedrezado del suelo.

Las figuras responden a las características ya comentadas para el resto de las esculturas del retablo, aquí talladas en planos más amplios y con posturas gesticulantes, que son las que recogen toda la expresividad de la escena, por tratarse de una pieza concebida para su contemplación a gran distancia; motivo este también por el que el tratamiento perspectivo resultaba forzado.

\footnotetext{
47 KRYNEN, 1959: 430-434.

48 RÉAU, 1997b: 275 y 279.

49 Óleo sobre lienzo, $245 \times 183 \mathrm{~cm}$, Museo del Louvre, inv. 3698. Pérez SÁnChez y NAVArRete Prieto, 2001: 120 y 238 , cat. 106.

${ }^{50}$ Agradezco al Dr. Benito Navarrete Prieto las indicaciones que con gran amabilidad me ha dado sobre esta iconografía.
}

Arch. esp. arte, LXXXVII, 348, OCTUBRE-DICIEMBRE 2014, 365-382

ISSN: 0004-0428, eISSN: 1988-8511, doi: 10.3989/aearte.2014.23 
$\mathrm{Al}$ igual que en otros muchos retablos barrocos, las esculturas de las cuatro virtudes cardinales adornaban el ático del altar mayor de San Luis (fig. 10). La identificación de su iconografía solo es posible en dos de las imágenes, las correspondientes a la Justicia (con un velo que cubre sus ojos, aludiendo a su proverbial ceguera, aunque habría perdido la balanza que suele llevar en las manos) y la Fortaleza (con un fuste de columna entre sus brazos), que flanquean el relieve de La Caridad de San Luis Obispo, a izquierda y derecha, respectivamente. Las restantes han perdido sus atributos, pero puede aventurarse que quizá la contigua a la Justicia fuera la Prudencia, pues parece que su mirada se dirige a una de sus manos, en la que habría sostenido originalmente un espejo, mientras que la última escultura representaría la Templanza, con una copa o un jarro de vino, perdido, en sus manos ${ }^{51}$.

Los tipos femeninos plasmados en los rostros son los habituales en las esculturas de Juan de Villanueva, de perfil ovalado y delicado, y las posturas, inestables, muy removidas y de gestos enfáticos. Pero es el diseño de las túnicas y mantos el que proporciona a las estatuas una belleza que sorprende, por tratarse de esculturas destinadas a un lugar elevado en el que podían pasar bastante inadvertidas. Estamos pues, en general, ante efigies de calidad y buenos ejemplos del decorativismo castizo y rococó que aflora en los años de plenitud de la producción de Juan de Villanueva ${ }^{52}$.

Completan el conjunto escultórico dos ángeles en las hornacinas laterales del ático (fig. 10), semiarrodillados y mostrando con sus gestos respeto y veneración a la imagen en relieve de San Luis que ambos flanquean y presentan. Son figuras dinámicas y con ropajes sacudidos y de abundantes drapeados, cuyas alas tienen un marcado carácter ornamental y rococó, pues recuerdan en su forma a molduras arriñonadas delimitadas por tornapuntas de "C", como las que se encuentran en los nervios de la bóveda de horno que flanquean a las estatuas.

\section{Conclusión}

Con todo lo expuesto, hemos querido, en definitiva, no solo recuperar la memoria de uno de tantos monumentos del antiguo Madrid hoy desaparecidos, sino, sobre todo, presentar este retablo mayor de la iglesia parroquial de San Luis Obispo como una de las principales obras de la producción retablística de madurez del escultor asturiano Juan de Villanueva y Barbales, y notable muestra de las consecuencias del arte de Churriguera en un período en que ya había comenzado en la Villa y Corte la transición entre el barroco exaltado casticista y el dieciochista preacadémico.

Aunque fueron muchos los insignes críticos e historiadores de los siglos pasados que, desde Ponz a Mesonero, vieron en este altar un ejemplo disparatado y extravagante de aquel "mal gusto churrigueresco" 53 . Habría que esperar al siglo XX y a la reivindicación del esplendor del barroco más exuberante y recargado, para leer que el retablo de San Luis estaba "magistralmente construido" o que había de ser obra de un "grandioso churrigueresco" que Elías Tormo pensaba sería alguno de los hijos del propio Churriguera ${ }^{54}$. Aunque no compartieran parentesco, Villanueva recogió sin duda el testigo de las fórmulas artísticas de ese genial a la par que controvertido artífice y su estilo podía ser fácilmente confundido con el de su ilustre y vilipendiado predecesor, y acaso maestro.

\footnotetext{
51 Para la iconografía de las virtudes, por ejemplo, EsteBAn LORENTE, 1998: 402-406.

52 Sobre estas esculturas y los modelos de figuras femeninas del escultor Villanueva, GARCía MENÉndEz, 2009: s/ núm.

53 Ponz, 1776: 249. Madoz, 1847: 714. Mesonero Romanos, 1831: 144; 1854: 274.

54 SChUbert, 1924: 197-198. TORmo, 1927: 146. TAMAYo (1946: 123-124) pensaba como Tormo en cuanto a la posible autoría del retablo.
} 


\section{BIBLIOGRAFÍA}

AA.VV, Marín. Fotografías 1908-1940, Madrid, Fundación Telefónica, 2007.

Agulló y Cobo, Mercedes, “Aportación documental a la biografía de Juan de Villanueva”, Gaceta del Museo Municipal de Madrid, 3 (1982): s/núm.

Amador de los Ríos, José, y Rada y Delgado, Juan de Dios de la, Historia de la Villa y Corte de Madrid, Madrid, Establecimiento Tipográfico de M. López de la Hoya, 1863, t. III.

Astiazarain Achabal, María Isabel, Miguel de Irazusta, San Sebastián, Diputación Foral de Guipúzcoa, 1997.

Basanta Reyes, María Belén, La parroquia de San Ginés de Madrid, Separata de Cuadernos de Arte e Iconografía, 17-18 (t. IX), 2000.

Bonet Correa, Antonio, "Los retablos de la iglesia de las Calatravas de Madrid. José de Churriguera y Juan de Villanueva, padre", Archivo Español de Arte (AEA), 137 (1962): 21-49.

Caramuel, Juan, Architectura civil recta y obliqua, considerada y dibuxada en el templo de Ierusalen, Vigevano, en la Imprenta Obispal por Camillo Corrado, 1678.

Castán Palomar, Fernando, "En el solar de la iglesia de San Luis", ABC, 9-XII-1942: 15.

Ceán Bermúdez, Juan Agustín, Diccionario histórico de los más ilustres profesores de las Bellas Artes en España. Madrid, Imprenta de la Vda. de Ibarra, 1800, 6 vols.

Esteban Lorente, Juan Francisco, Tratado de Iconografia, Madrid, Ediciones Istmo, 1998.

García Menéndez, Bárbara, "La impronta del escultor Juan de Villanueva y Barbales (1681-1765) en el arte barroco asturiano del siglo XVIII”, Liño, 13 (2007): 57-68.

García Menéndez, Bárbara, El escultor y académico Juan de Villanueva y Barbales (1681-1765), Universidad de Oviedo, tesis doctoral inédita, 2009, 4 vols.

García Menéndez, Bárbara, "El ideal de belleza femenina del escultor Juan de Villanueva y Barbales", en Congreso Internacional "Imagen y Apariencia”, Universidad de Murcia, 2009: s/núm.

García Menéndez, Bárbara, "El escultor Juan de Villanueva y la colonia de artistas asturianos en el Madrid de la primera mitad del siglo XVIII", Liño, 15 (2009): 73-82.

García Menéndez, Bárbara, Juan de Villanueva y Barbales (1681-1765), un escultor poleso del siglo XVIII, Pola de Siero, IES “Escultor Juan de Villanueva”, 2010.

García Menéndez, Bárbara, "La biblioteca del escultor Juan de Villanueva y Barbales (1681-1765)", BSAA Arte, LXXVI (2010): 215-240.

García Menéndez, Bárbara, "Un heresiarca en la Academia. La formación de Diego de Villanueva como escultor y arquitecto retablista en el entorno del churriguerismo", Goya. Revista de arte, 337 (2011): 312-323.

García Menéndez, Bárbara, "La ciudad y sus habitantes: una comunidad de artistas en el barrio del Barquillo, en Madrid, en la primera mitad del siglo XVIII", en XVIII Congreso CEHA. Mirando a Clío. El arte español espejo de su historia, Universidad de Santiago de Compostela, 2012, pp. 2943-2955.

García Menéndez, Bárbara, "Una obra inadvertida de Luis Salvador Carmona en Madrid”, Cuadernos de Estepa 2 (2013): 135-143.

Gaya Nuño, Juan Antonio, La pintura española fuera de España (historia y catálogo), Madrid, Espasa Calpe, 1958.

González Santos, Javier, La catedral de Oviedo. Sancta Ovetensis, León, Edilesa, 1998.

Held, Julius S., Taylor, René, y Carder, James N., Museo de Arte de Ponce. Fundación Luis A. Ferré. Catalogue. Paintings and sculpture of the European and American Schools, Ponce, Puerto Rico, 1984.

Krynen, Jean, "San Luis de Anjou”, Año Cristiano, t. III, Madrid, Ed. Católica (BAC 185), 1959.

López Sánchez, Fernando, Pedro Ruiz González (h. 1638/1642-1706). Pintor barroco madrileño, Madrid, Ayuntamiento de Madrid, 2007.

Lorente Junquera, Manuel, “Los relieves marmóreos del Palacio Real”, Arte Español, XX (1954): 58-71.

Madoz, Pascual, Diccionario geográfico-estadístico-histórico de España y sus posesiones de ultramar, Madrid, 1847, t. X.

Mesonero Romanos, Ramón de, Manual de Madrid. Descripción de la Corte y de la Villa, Madrid, Imprenta de D. M. de Burgos, 1831.

Mesonero Romanos, Ramón de, Escenas matritenses. Primera época (1832 á 1836), en Los españoles pintados por sí mismos. Por varios autores. Adornada con cien grabados, Madrid, Gaspar y Roig, 1851.

Arch. esp. arte, LXXXVII, 348, OCTUBRE-DICIEMBRE 2014, 365-382

ISSN: 0004-0428, eISSN: 1988-8511, doi: 10.3989/aearte.2014.23 
Mesonero Romanos, Ramón de, Nuevo manual histórico-topográfico-estadístico y descripción de Madrid por D. - . Adornado con grabados, Madrid, Imprenta de la Vda. de Antonio Yenes, 1854.

Palomino y Velasco, Antonio Acisclo, El Museo pictórico y escala óptica. Tomo segundo. Práctica de la pintura, Madrid, Viuda de Juan García Infanzón, 1724.

Paredes Alonso, Javier, Mercaderes de libros. Cuatro siglos de historia de la Hermandad de San Gerónimo, Madrid, Fundación Germán Sánchez Ruipérez, 1988.

Pérez Sánchez, Alfonso Emilio, Pintura barroca en España. 1600-1750, Madrid, Manuales de Arte Cátedra, 2010.

Pérez Sánchez, Alfonso Emilio y Navarrete Prieto, Benito, Luis Tristán, h. 1585-1624, Madrid, Real Fundación de Toledo-Fundación BBVA, 2001.

Plaza Santiago, Francisco Javier de la, Investigaciones sobre el Palacio Real Nuevo de Madrid, Valladolid, Universidad de Valladolid, 1975.

Ponz, Antonio, Viage de España, Madrid, Joaquín Ibarra, 1776, t. V.

Portela Sandoval, Francisco Javier, "Panorama actual de la escultura religiosa en Madrid (1500-1750)", Cuadernos de Historia y Arte, IV (1986): 47-96.

Pozzo, Andrea, Perspectiva Pictorum et Architectorum, Roma, Joannis Jacobi Komarkek, 1693-1700, 2 vols.

Ramallo Asensio, Germán, Escultura barroca en Asturias, Oviedo, Instituto de Estudios Asturianos, 1985.

Réau, Louis, Iconografía del arte cristiano. Iconografia de los santos. De la A a la F, Barcelona, Ediciones del Serba, 1997, t. 2, vol. 3.

Réau, Louis, Iconografia del arte cristiano. Iconografía de los santos. De la G a la O, Barcelona, Ediciones del Serbal, 1997, t. 2, vol. 4.

Rodríguez G. de Ceballos, Alfonso, Los Churriguera, CSIC, 1971.

Ruiz Argilés, Vicente, "Una iglesia madrileña desaparecida. San Luis Obispo", AEA, 101 (1953): 37-50.

Saltillo, Marqués del, "Arquitectos y alarifes madrileños del siglo XVII (1615-1699)", Boletín de la Sociedad Española de Excursiones, LII (1948): 161-221.

Sánchez Cantón, Francisco Javier, "Pedro Ruiz González, pintor de la escuela de Madrid", AEA, 60 (1943): 399-403.

Schubert, Otto, Historia del Barroco en España, Madrid, Saturnino Calleja, 1924.

Tamayo, Alberto, Las iglesias barrocas madrileñas, Madrid, 1946.

Tárraga Baldó, María Luisa, "Los relieves labrados para las sobrepuertas del Palacio Real de Madrid", $A E A$, 273 (1996): 45-67.

Tercero, Manuel, "La madrileñísima iglesia de San Luis, desaparece”, ABC, 19-III-1943: 12.

Tormo y Monzó, Elías, Las iglesias del Antiguo Madrid, Madrid, Instituto de España, 1979 (reed. de la ed. de 1927, con prólogo y notas de Gómez-Moreno, María Elena).

Tovar Martín, Virginia, "El arquitecto Marcos López y el convento de Trinitarias Descalzas de Madrid", Anales del Instituto de Estudios Madrileños, X (1974): 133-153.

Tovar Martín, Virginia, Arquitectos madrileños de la segunda mitad del siglo XVII, Madrid, Instituto de Estudios Madrileños, 1975.

Tovar Martín, Virginia, "Tres proyectos del arquitecto madrileño del siglo XVIII Francisco Ruiz”, Revista de la Biblioteca, Archivo y Museo del Ayuntamiento de Madrid, 1-2 (1977): 111-128.

Urrea Fernández, Jesús, "Una propuesta para el escultor Pablo González Velázquez”, BSAA, XLIII (1977): 484-488.

Villanueva, Diego de, Libro de diferentes pensamientos, unos imbentados y otros delineados por -, año de 1754, 1754 (edición, Madrid, Academia de San Fernando, con introducción y notas de Reese, Thomas, 1979).

Fecha de recepción: 13-XII-2013

Fecha de aceptación: 13-V-2014 


\title{
LOS ANUARIOS DE FOTOGRAFÍA EN ESPAÑA DE 1946 Y 1948 EDITADOS POR LA REVISTA SOMBRAS
}

\author{
Juan Miguel Sánchez Vigil y María Olivera Zaldua \\ UNIVERSIDAD COMPLUTENSE DE MADRID
}

Si la fotografía no es un arte clásico, es, por lo menos, el medio de expresión de muchos artistas.

Eduardo Susanna

Anuario Sombras, 1946

El primer anuario sobre fotografía española se publicó antes de la guerra civil, en 1924, y hasta casi un cuarto de siglo después, en 1946, no salió el segundo, editado por la revista Sombras, órgano de difusión de la Real Sociedad Fotográfica de Madrid. El objetivo fue mostrar la fotografía del momento, presentando las creaciones y las novedades técnicas. Con el mismo propósito, esa institución editó un segundo anuario en 1948, con estructura y contenidos similares. Ambas publicaciones contienen documentación fundamental para el estudio de los autores y sus obras, el desarrollo profesional y amateur, las sociedades y agrupaciones fotográficas, así como de la evolución técnica. Se realiza en este artículo un análisis de ambos anuarios con el objetivo de aportar nuevos datos a la historia de la fotografía española desde los aspectos artístico, informativo y documental.

Palabras clave: Anuario fotográfico; Arte fotográfico; Fotografía; Historia de la fotografía española; revista Sombras.

\section{SPAIN'S PHOTOGRAPHY YEARBOOKS OF 1946 AND 1948, PUBLISHED BY SOMBRAS MAGAZINE}

The first yearbook of Spanish artistic photography was published before the Civil War in 1924, but it was not until twenty-five years later that the second one was printed by Sombras magazine, of the Real Sociedad Fotográfica de Madrid. It was intended to reflect the situation of photography at the time by presenting the latest creations and technical innovations. With this same goal in mind, that society published a second yearbook in 1948, with similar structure and contents. Both publications contain basic documentation for the study of the photographers and their works, professional and amateur development, photographic associations and groups, as well as technical evolution. Both yearbooks are analyzed in this article in order to provide new information on the history of Spanish photography from the artistic, informative and documentary points of view.

Key words: Photographic yearbook; Photographic Art; Photography; History of Spanish Photography; Sombras magazine. 


\section{Introducción}

La historia de la fotografía tienes muchas lecturas, y fundamentalmente tres relacionadas con la autoría, la ubicación temporal y espacial, y los contenidos. Anne McCuley ha considerado que "El concepto de historia única y lineal de la fotografía también fracasa a la hora de abordar los problemáticos límites de lo fotográfico"1. Por lo que respecta al estudio histórico se han aplicado diversas metodologías, desde la cronológica hasta la obra de autor, si bien todos los planteamientos están sometidos a debate por los investigadores ${ }^{2}$. Una de las fuentes fundamentales en la investigación sobre la materia son los anuarios, cuyo valor en un espacio y tiempo concretos es de gran importancia ya que son un referente de la creación y las tendencias, si bien absolutamente

\section{ANNU AIRE}

\section{PHOTOGRAPHIQUE}

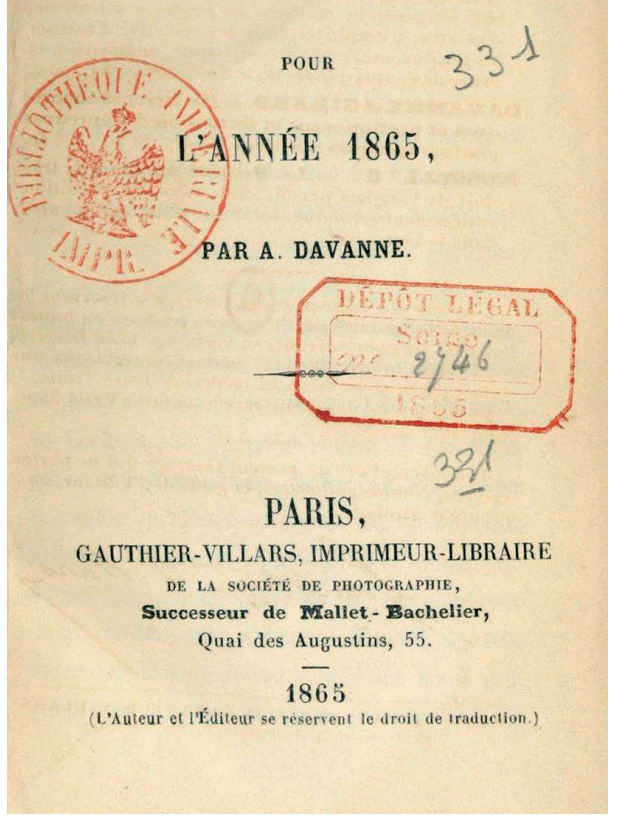

Fig. 1. Annuaire Photographique. París, 1865. subjetivo cuando se trata de selecciones con criterios particulares como en el caso que nos ocupa. Aún así, al tratarse de obras de referencia son claves en toda investigación, como se indica en la definición del Diccionario Enciclopédico de las Ciencias de la Documentación: "Documento que recoge los últimos acontecimientos producidos a lo largo de un año sobre diferentes materias y contenidos" ${ }^{3}$. Por consiguiente los matices serán diversos en función de la entidad que los publica, los objetivos y el tipo de información recopilada.

El primer anuario de fotografía fue editado en Francia por Alphonse Davanne en 1865, apenas un cuarto de siglo después de que Daguerre presentara su invento en París. Se tituló Annuarie photographique (fig.1) y su contenido fue sobre procedimientos e innovaciones. Treinta años después, en 1895, Francis James Mortimer comenzó a editar en Londres el anuario Photograms of the year, dando ya tanto valor a los autores y a sus obras como a la técnica.

En España, el primer anuario salió en 1924 y hasta 1946 no se publicaría el segundo, evidenciando un claro distanciamiento con Europa. Algunos historiadores han considerado como primer anuario de la fotografía española el editado por la Agrupación Fotográfica Almeriense (Afal) en 19584, como se indica en el texto "Arte Fotográfico" en la web del Centro Virtual Cervantes ${ }^{5}$. Sin embargo treinta años antes la Revista Fotográfica de Barcelona ha-

1 Newhall, 2002: 300.

2 FONTCUBERTA, 2008: 14.

3 López Yepes (editor), 2004: t. ${ }^{\circ}$ I, 69.

${ }^{4}$ El Anuario Afal de 1958 es el cuarto en la historia de la fotografía española, editado veinte años después del término de la guerra civil.

${ }^{5}$ Centro Virtual Cervantes (2013). El papel de la fotografia. Afal. Introducción.

http://cvc.cervantes.es/artes/fotografia/papel_foto/afal/introduccion.htm [Consulta: 25 marzo de 2013] 
bía patrocinado el primer Anuario Fotográfico Español ${ }^{6}$, cuyo propósito fue dar a conocer las mejores obras de los pictorialistas. La publicación coincidió con la edición del catálogo del XX Salón Internacional de Fotografía organizado en París por la Societé Française de Photographie 7 , en el que participaron 48 autores y entre ellos dos españoles: José Ortiz Echagüe con la obra Labriego castellano, y el Conde de la Ventosa con Vieja iglesia y mujeres.

La actividad fotográfica en la posguerra se desarrolló en torno a las sociedades, especialmente a la Agrupación Fotográfica de Catalunya en Barcelona y a la Real Sociedad Fotográfica de Madrid $^{8}$. La mayoría de las asociaciones contaron con boletines informativos, y la sociedad madrileña publicó la revista La Fotografía entre 1900 y 1914, dirigida por Antonio Cánovas del Castillo y Vallejo (Kaulak), que en 1904 llegó a tirar 3.000 ejemplares9. La Sociedad Fotográfica de Madrid creó después la revista Sombras (1944-1954) como órgano de difusión y plataforma de las creaciones y actividades de sus miembros, y dentro de ese período (1946 y 1948) se publicaron los dos anuarios que analizamos. En el resto del país la actividad en las asociaciones y entidades culturales fue reducida pero constante, con nueve grupos censados en Sombras en 1946: cuatro en Cataluña y el resto en Madrid, Elche, Valencia, Zaragoza y Écija, más otras seis asociaciones en proceso de creación: Andalucía, Asturias, Guipúzcoa, Orihuela, Novelda y Vigo. Dos años después, en 1948, se sumaron cinco secciones de fotografía vinculadas a centros excursionistas.

En la historiografía sobre la materia son escasas las referencias a la década de los cuarenta y prácticamente nulas a los anuarios publicados por Sombras, con excepción de Mónica Carabias ${ }^{10}$. Esa década fue "traumática y oscura", como indica Carlos Cánovas, porque la actividad de los fotógrafos con talento fue silenciada y porque no se daban las condiciones mínimas para relanzar la fotografía ${ }^{11}$.

Es objeto de este artículo analizar los contenidos de ambos anuarios, teniendo en cuenta el antecedente de 1924, con el fin de cubrir la falta de información a la que aluden los historiadores. Se pretende por tanto investigar sobre los autores y sus obras, las asociaciones y las empresas, para contribuir a un mayor y más profundo conocimiento de la fotografía española en la posguerra.

La metodología empleada, tras la revisión de la bibliografía, ha sido la elaboración de una base de datos para el vaciado completo de los contenidos de los anuarios, con el fin de obtener los nombres de los autores, los títulos de las obras, así como los profesionales dedicados a la fotografía. Posteriormente se han analizado las obras y se ha realizado el estudio comparativo entre anuarios para obtener los resultados que se presentan en las tablas elaboradas al efecto. Se ha llevado a cabo también la selección y reproducción de las obras que se consideran representativas para incluirlas como ilustración al texto. Finalmente se han añadido dos anexos con los fotógrafos del Anuario de 1924 y los profesionales censados en España entre 1946 y 1948.

\section{El primer anuario fotográfico español}

La Revista Fotográfica ${ }^{12}$ de Barcelona patrocinó en 1924 el Anuario de la Fotografía Española, editado por la empresa Pal-Las S.A., en cuya portada se indicaba: "Primero de su publica-

${ }^{6}$ Anuario Fotográfico Español. Barcelona: Pal-Las. Revista Fotográfica, 1924.

7 XX Salon International de Photographie. París: Braun \& Cíe. Éditeurs, 1925.

${ }^{8}$ Martín López y MuÑoz García, 2004.

9 Molinero Cardenal, 2001: 89.

10 Carabias, 2011: 53-54.

11 CÁnOvas, 1992: 11.

12 Revista Fotográfica fue fundada por Vincens Caldés Arús en Barcelona, propietario del comercio fotográfico del mismo nombre. Salió en julio de 1923 y cerró en junio de 1925. Se publicaron 21 números y la información era prioritariamente de carácter técnico, con artículos traducidos de Leancourt, Ch. Duvivier, Otto Siebert y G. Cher. Las ilustraciones eran escasas, con una media de dos fotos por ejemplar.

Arch. esp. arte, LXXXVII, 348, OCTUBRE-DICIEMBRE 2014, 383-400

ISSN: 0004-0428, eISSN: 1988-8511, doi: 10.3989/aearte.2014.24 
ción”. El modelo de referencia en cuanto a la forma (tamaño y diseño) fue el anuario británico Photograms of the year. Los criterios de selección de los 50 autores y obras (anexo 1; figs. 2 y 3) reproducidas en las 64 páginas del libro se explican en el editorial, dando preferencia a los temas inéditos. Su contenido se estructuró en cuatro partes: Introducción, Índice de autores y obras, Fotografías seleccionadas y Publicidad (9 páginas de 64), con anuncios de las principales firmas de cámaras, óptica, mecánica, películas y papeles: Voigtlander, Cappelli, Perutz, Agfa, Eastman, Bayer y Reitzschel. El objetivo del Anuario quedó expuesto en la introducción (sin firma) incluida la crítica a la técnica de los autores:

El propósito inicial, el que nos impulsó a emprender el esfuerzo, fue el de dar a conocer las mejores obras de artistas españoles, obtenidas por medio de la fotografía... Se halla en la mayoría de las obras fotográficas de autores españoles una gran dosis de ingenio, de buen gusto, de inspiración. Sin ser su técnica superior a la de los franceses e italianos, ni llegar al grado de perfección de los americanos, de los alemanes ni de los rusos, tienen en cambio sus concepciones una belleza, una vida y una fuerza de humanidad.

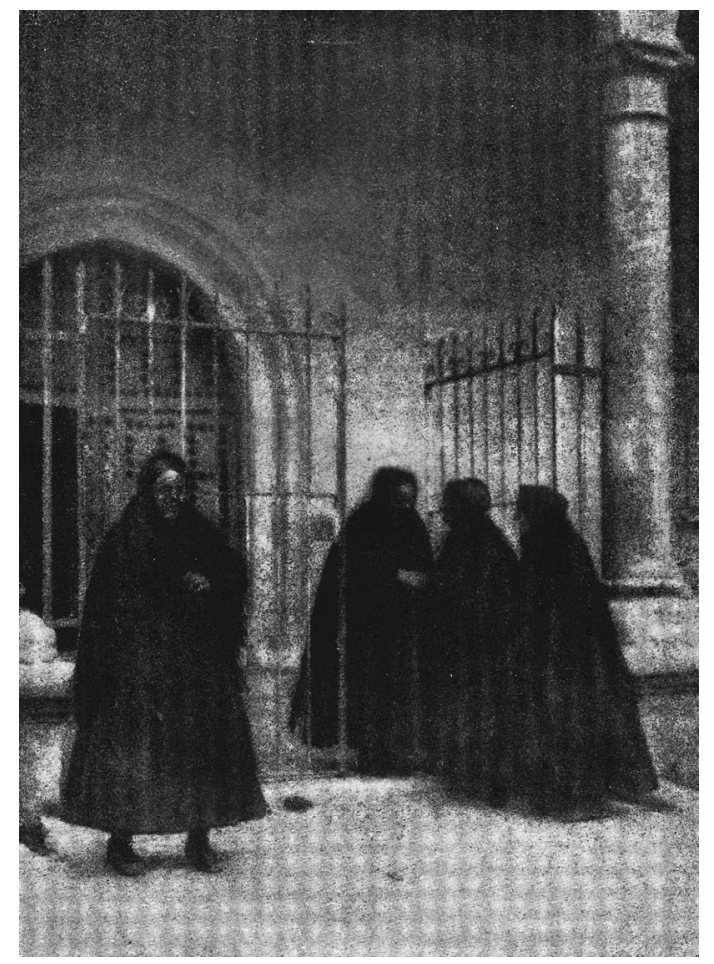

Fig. 2. Francisco Andrada. Beatas. Anuario de 1924.

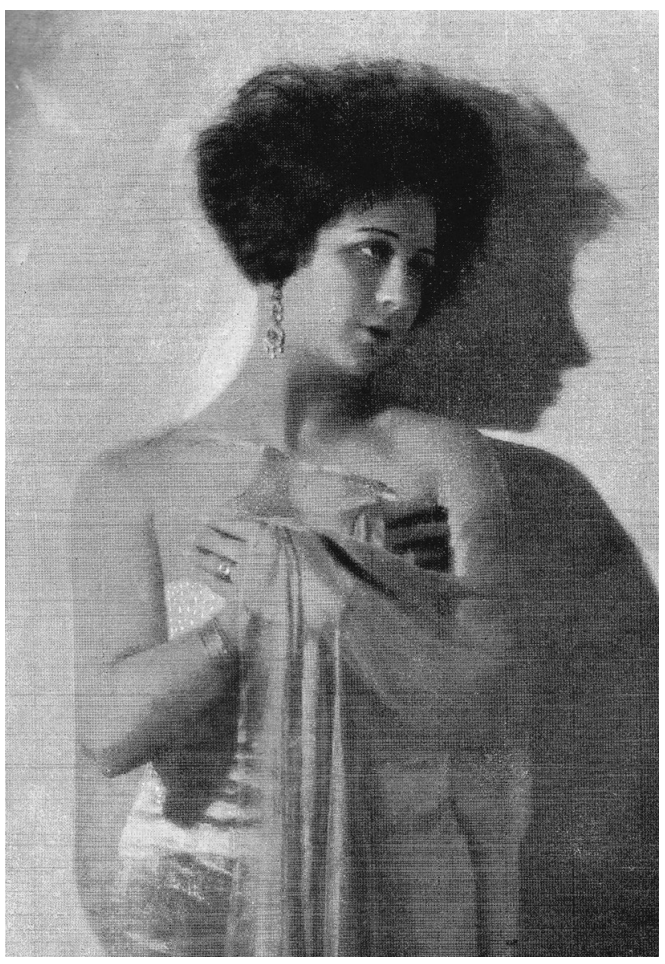

Fig. 3. José Massana. Estudio. Anuario de 1924.

Las observaciones del editor en el preámbulo nos advierten que "los concursos escaseaban, las exposiciones eran mínimas y la organización de salones prácticamente imposible". Las fotos seleccionadas respondían a la corriente pictorialista dominante, realizadas en buena parte por autores de prestigio, entre ellos: Francisco Andrada, Rafael Areñas, Antoni Arissa, Vicente Mar- 
tínez Sanz, Josep Massana, Vicente Novella, Ortiz Echagüe, Eduardo Susanna o Joaquín Vilatobá. Por lo que respecta a la temática, se establecieron cuatro apartados: Paisajes, Retratos, Escenas de costumbres y Bodegones, con equilibro en cuanto a la cantidad. Es significativo el hecho de que se hiciera una llamada en la portadilla a los autores españoles, y a los extranjeros afincados en el país, con objeto de preparar el anuario del año 1925, que finalmente solo quedó en proyecto.

\section{La revista Sombras y los anuarios}

Apenas un sexenio después del final de la guerra civil, con una economía inexistente y en un momento político de incertidumbre por las posibles consecuencias tras la derrota alemana en la contienda mundial, salió la revista de fotografía Sombras, la única en la especialidad y por tanto el escaparate de la creación en aquel momento, aunque según Horacio Fernández el papel de las revistas fue realizar "Evocaciones de pinturas o grabados compuestos a base de contornos difuminados, retoques y atmósferas nubladas"13. López Mondéjar indica en su Historia de la Fotografía Española que el arte de posguerra, tras la victoria militar de 1939, era concebido como "Algo meramente ceremonial, puesto al servicio del Estado y del Imperio"14.

Sombras fue fundada por la Real Sociedad Fotográfica, entidad creada en Madrid en 1899. Mónica Carabias ${ }^{15}$ establece tres etapas en el desarrollo de la publicación: la primera entre junio de 1944 y octubre de 1946 bajo la dirección de su fundador Domingo de Luis, la segunda hasta noviembre de 1949 coordinada por Francisco Velilla, y la tercera con límite en noviembre de 1954 con José Ventura y Cristóbal Batalla al frente. Vicente Castedo, vicepresidente de la institución en 1944, se encargo del editorial de presentación, en el que se indicaba que la revista era "Para cuantos practican el noble deporte de la fotografía y para aquellos que hacen de este arte su vivir cotidiano"16:

Pocas veces pudo decirse de una publicación tan apropiadamente que viene a llenar un vacío, por mucho que el abuso haya disminuido el valor de la frase. Lo demuestra su añorada necesidad, por no existir otra análoga en España; su valor, por igualarse a las más preciadas extranjeras; su programa completo en la técnica y en la literatura; sus firmas prestigiosas, ante las cuales la mía se empequeñece, y sus iniciativas, propósitos y esfuerzos financieros para alcanzar y consolidar los resultados.

Mantener una publicación especializada en fotografía durante aquella década fue todo un reto, superado con la cuidada presentación (papel especial e impresión en huecograbado) y con la participación de la mayoría de los autores creativos. Los dos últimos años coincidió con Arte Fotográfico, fundada en 1952 por Diego Gálvez, quien cedió la propiedad a Ignacio Barceló.

En el período de edición de Sombras se publicaron, en 1946 y 1948, los dos anuarios a que ya nos hemos referido, y que coincidieron con la creación de la mítica agencia Magnum en Estados Unidos el año 1947 por Cartier-Bresson, Rodger, Capa y Seymour ${ }^{17}$. Los objetivos generales fueron presentar el trabajo de los autores y sus obras, así como las novedades técnicas, informar a los profesionales y aficionados sobre las agrupaciones y sociedades, y censar las empresas en activo. En el análisis de los contenidos se advierten otros propósitos como la difusión de la publicación entre los profesionales y aficionados incluidos en el libro. La financiación

\footnotetext{
13 FERnÁndeZ, H., 1996: 17.

14 LÓPEZ MONDÉJAR, 1997: 178.

15 CARABIAS, 2008: 15-22.

16 SÁNCHEZ Vigil, 2007: 44.

17 Molinero Cardenal, 2001: 330-335.
}

Arch. esp. arte, LXXXVII, 348, OCTUBRE-DICIEMBRE 2014, 383-400

ISSN: 0004-0428, eISSN: 1988-8511, doi: 10.3989/aearte.2014.24 
se consiguió fundamentalmente con la publicidad de tres firmas de prestigio: Kodak, Gevaert y Valca, más la del resto de proveedores con menor peso específico.

Los fotógrafos censados en 1946 fueron 1.599 (gráfico 1), con un ligero descenso a 1.588 en 1948. El 25\% de las empresas (400) se encontraban en Madrid y Barcelona, con claro predominio de esta última; 14 provincias, incluidas Melilla y las localidades del Protectorado, sumaban el 35\% (600 empresas), y en las 37 provincias restantes se distribuía el resto.

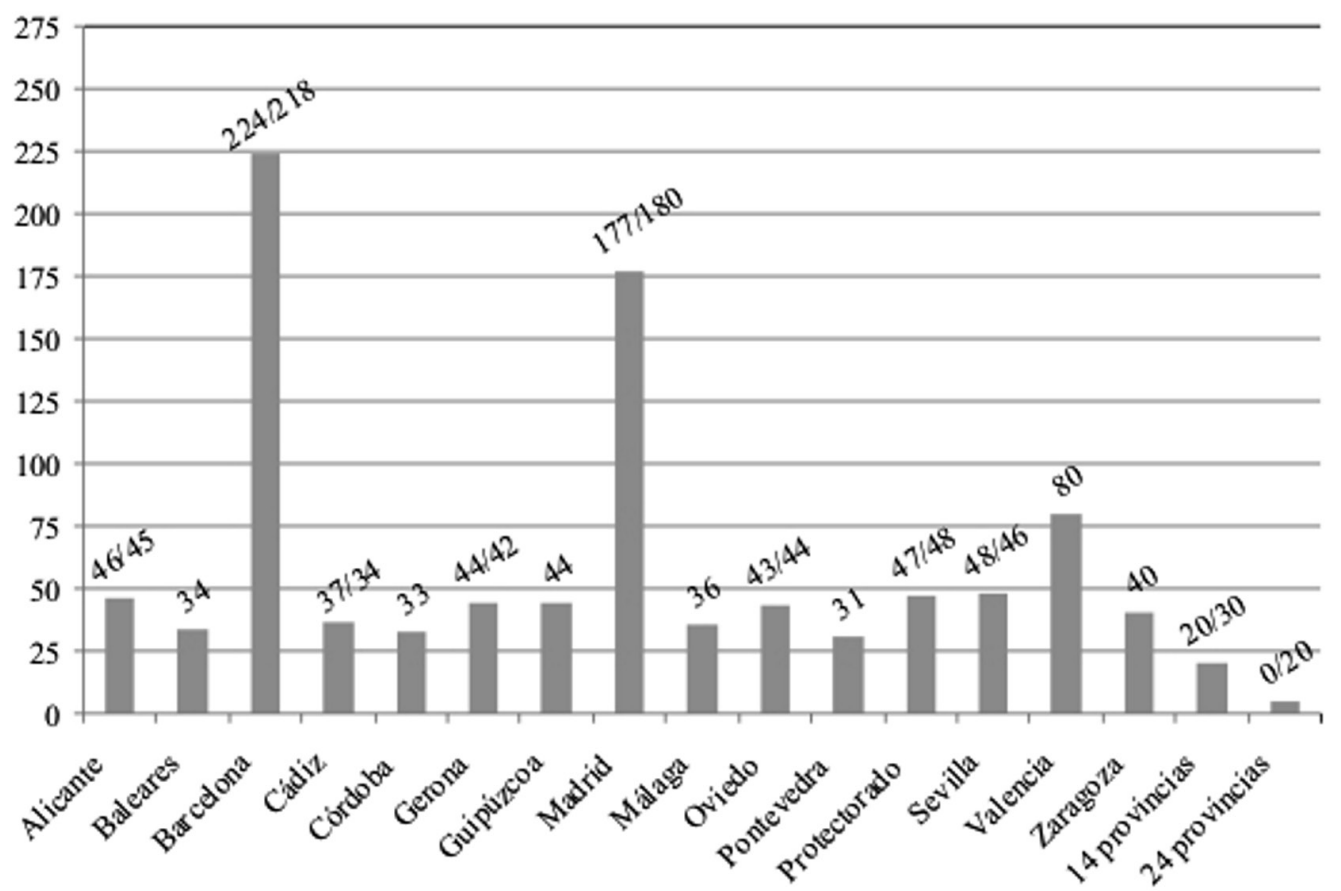

Gráfico 1. Fotógrafos censados en los anuarios de Sombras (1946/1948).

\section{Anuario de 1946}

El anuario de 1946 fue dirigido por el ingeniero militar Eduardo Susanna Almaraz, redactor de la revista Sombras y vicepresidente de la Real Sociedad Fotográfica de Madrid, mientras que Domingo de Luis, fundador de la revista fue el editor. Susanna, cuya obra figuró entre las elegidas para el anuario de 1924, se había formado en el pictorialismo, había experimentado todos los procedimientos pigmentarios desde los años veinte, y había creado el taller Construcciones Fotográficas para la reparación de aparatos y la adaptación de lentes en las cámaras Leica y Contax.

El anuario se concibió como "Una enciclopedia que ha de filtrar cuidadosamente todas las novedades del año, incorporando todo lo que haya de útil". Con este concepto Susanna se refería a los procedimientos fotográficos y sus actividades (teoría y práctica), y a la concepción y realización de la obra (circunstancias del artista). 
Se encuadernó en tela azul estampada en oro, dividido en tres partes: textos, ilustraciones, y listados de suscriptores, profesionales y agrupaciones fotográficas. Los textos se abrían con el prólogo, seguido de tres capítulos técnicos: el primero sobre el color (tres artículos), el segundo sobre el positivado y los procedimientos (ocho artículos), y el tercero sobre las novedades y datos prácticos (4 artículos). En el prólogo se reivindicaba el carácter artístico de la fotografía:

Si la fotografía no es un arte clásico, es por lo menos el medio de expresión de muchos artistas. Nadie puede negar la posibilidad de producir fotográficamente una obra bella. La misma cámara, con el mismo objetivo y el mismo material y procedimientos, pueden dar lugar, según las manos que los manejen, a resultados totalmente diferentes, aún con idéntico modelo e idéntico tema.

Se seleccionaron 40 fotos de 34 autores (tabla 1), reproducidas en 32 páginas, con un extenso comentario para cada una de ellas firmado por "Cromófilo", más 6 imágenes de aficionados (Miguel Herrero, Elisenda, Caamaño, Castillo, Lucy Esquerdo y J. Álvarez) que ya habían sido publicadas y comentadas en la revista. Todas las obras reflejan la corriente imperante, definida como "tardopictorialismo" y representadas por los clásicos de los años veinte y treinta, con excepción de Aurelio Grasa formado en el fotoperiodismo y vinculado a las vanguardias tras viajar a París en los años veinte, donde contactó con los autores de la corriente Nueva Objetividad, publicando en National Geographic Magazine y la Revue Moderne.

Cuatro de los autores que habían publicado en el anuario de 1924 repitieron la experiencia: Eduardo Susanna, Francisco Andrada, el conde de la Ventosa y José Ortiz Echagüe, de cuya fotografía se dice: "No haría falta la firma para saber que Novia sin sotana es un obra de Ortiz Echagüe. Hace muchos años que este maestro indiscutible de la fotografía creó un estilo inimitable y permanece fiel a él a través de toda su magnífica obra de fotografías de España”.

Los criterios de selección son cuestionables, ya que se incluyen dos obras que datamos antes de la guerra civil: la primera, titulada En el ruedo, de Manuel Cervera, tomada en la corrida de

Tabla 1. Autores del anuario Sombras de 1946.

\begin{tabular}{|l|l|}
\hline \multicolumn{1}{|c|}{ Autor } & \multicolumn{1}{c|}{ Titulo } \\
\hline Alfonso & Jacinto Benavente \\
\hline Andrada, F. & Albercaza \\
\hline Asensi, L. & Barquitos \\
\hline Bau, Joaquín & Aceite \\
\hline Bonoso de Arcos & Holandesa \\
\hline Campañá, Antoni & Y vinieron \\
\hline Carbolleu, C. & Estampa marroquí \\
\hline Carreras Soley, D. & Fluvius \\
\hline Cartajena (sic) & Mariano Benlliure \\
\hline Cervera, Manuel & En el ruedo \\
\hline Corbella, Luis & Estudio \\
\hline Franzen & Retrato \\
\hline Gálvez, Diego & Amanecer de reyes \\
\hline Garay, Daniel & Estudio \\
\hline Gonzaléz Aguilar & Sombras transparentes \\
\hline Grasa, Aurelio & Reflejo \\
\hline Irurzun, Pedro M. & Espigas \\
\hline
\end{tabular}

\begin{tabular}{|l|l|}
\hline \multicolumn{1}{|c|}{ Autor } & \multicolumn{1}{c|}{ Titulo } \\
\hline Jiménez, Julio & Muñecas \\
\hline Lozano, J. & En el tendido \\
\hline Macías Rodríguez, P. & La risa del zagal \\
\hline Manuel & Estudio \\
\hline Mora Carbonell, F. & Días y años \\
\hline Núñez, J. & Desolación \\
\hline Ollé, Antonio & Borrasca \\
\hline Ortiz Echagüe & Novia ansotana \\
\hline Pajares, A. & Los cuatro postes \\
\hline Palau, Antonio & Luz solar \\
\hline Pla Janini, J. & Plafón decorativo \\
\hline Sánchez Ors & En Semana Santa \\
\hline Soriana, Marqués de & La cosecha \\
\hline Susanna, Eduardo & Moza de cántaros \\
\hline Tinoco, José & Negro y blanco \\
\hline Vallmitjana, A. & Vejer de la Frontera \\
\hline Ventosa, Conde & Bruma \\
\hline
\end{tabular}

Arch. esp. arte, LXXXVII, 348, OCTUBRE-DICIEMBRE 2014, 383-400

ISSN: 0004-0428, eISSN: 1988-8511, doi: 10.3989/aearte.2014.24 
toros de Toledo en 1918, y la segunda el retrato de Jacinto Benavente realizado a mediados de los veinte por Alfonso en su estudio de la calle Fuencarral. Puede interpretarse la inclusión de estas dos fotografías como un guiño a los clásicos, e incluso como reivindicación de esto autores, ya que Alfonso había sido depurado al término de la guerra por su actividad fotoperiodística.

Del análisis de los contenidos resultan cuatro temas generales: Retratos (19 fotografías), Paisajes y vistas (7), Escenas y costumbres (10) y Composiciones (4). Prácticamente la mitad de las imágenes son retratos, mientras que escasean las composiciones, características de la vanguardia en el período de entreguerras. Se observa una miscelánea de obras, autores y estilos, reflejo de un momento de transición, con fuertes reminiscencias del pasado y del clasicismo, muy obvio en los retratos de estudio, como en los casos de Luis Corbella o Daniel Garay (fig. 4), que en el titulado Estudio imita la pintura de Julio Romero de Torres, incluida la guitarra española. Son clásicos también los tipos populares ataviados con trajes regionales (Ortiz Echagüe, Susanna, Francisco Andrada y Bonoso de Arcos) y las escenas costumbristas (Mora Carbonell), y no se comprende, por su simpleza, la selección del retrato de Mariano Benlliure realizado por Cartajena (sic).

Los paisajes se resuelven con encuadres convencionales y una estética desfasada. La obra Borrasca de Antonio Ollé Pinell, autor de la Enciclopedia de la Fotografia, es la de peor calidad, y el resto es mediocre, con excepción de Reflejo, de Aurelio Grasa, y Bruma del Conde de la Ventosa (fig. 5). En cuanto a las composiciones, la obra más destacada por la dificultad técnica es la titulada Plafón decorativo de Pla Janini; y rompen la monotonía las obras de Sánchez Ors con un contrapicado de una escena de Semana Santa y Amanecer de Reyes, de Diego Gálvez, muy vanguardista y con gran dominio de la luz y las sombras (fig. 6). El soplo de aire fresco está en las fotografías de los aficionados, de peor calidad técnica y con encuadres menos trabajados, pero más documentales y ricas en detalles.

Por lo que respecta a las agrupaciones y sociedades de las que formaban parte amateurs y profesionales, figuran nueve, seis de ellas dedicadas exclusivamente a la fotografía, más tres secciones de entidades culturales. Cuatro se encontraban en Cataluña (dos en Barcelona, una en Igualada y la cuarta en Villanueva y la Geltrú), más las de Madrid, Zaragoza, Valencia, Elche y Ecija. Asimismo, se indica que se encontraban en formación la Agrupación Fotográfica Andaluza y Asturiana, más dos sociedades en Orihuela y Novelda (tabla 2).

Tabla 2. Anuario Sombras. Sociedades y Secciones Fotográficas en 1946.

\begin{tabular}{|l|l|l|}
\hline \multicolumn{1}{|c|}{ Agrupación } & \multicolumn{1}{c|}{ Localidad } & \multicolumn{1}{c|}{ Presidente } \\
\hline Fotográfica de Cataluña & Barcelona (Duque de Victoria 14) & Manuel Ballespi \\
\hline Fotográfica de Igualada & Igualada (Barcelona, San Jaime 6) & Pedro Borrás \\
\hline Foto Club de Valencia & Valencia (Paz 26) & Francisco Caps Dais \\
\hline Peña Fotográfica Elche & Elche (Alicante) & Gabriel R. Chorro \\
\hline Real Sociedad Fotográfica & Madrid (Príncipe 16) & Conde de la Ventosa \\
\hline Fotográfica de Zaragoza & Zaragoza (Plaza de Sas 7) & Lorenzo Almarza \\
\hline \multicolumn{1}{|c|}{ Secciones } & \multicolumn{1}{|c|}{ Localidad } & \multicolumn{1}{c|}{ Presidente } \\
\hline \multicolumn{1}{|c|}{ Villanueva y Geltrú } & Barcelona & Alfonso Foradada Coll \\
\hline Centro Exc. de Cataluña & Barcelona (Plaza del Pino 5) & Juan Pi \\
\hline Club Artístico de Écija & Sevilla & Eloy Herrera Pineda \\
\hline
\end{tabular}




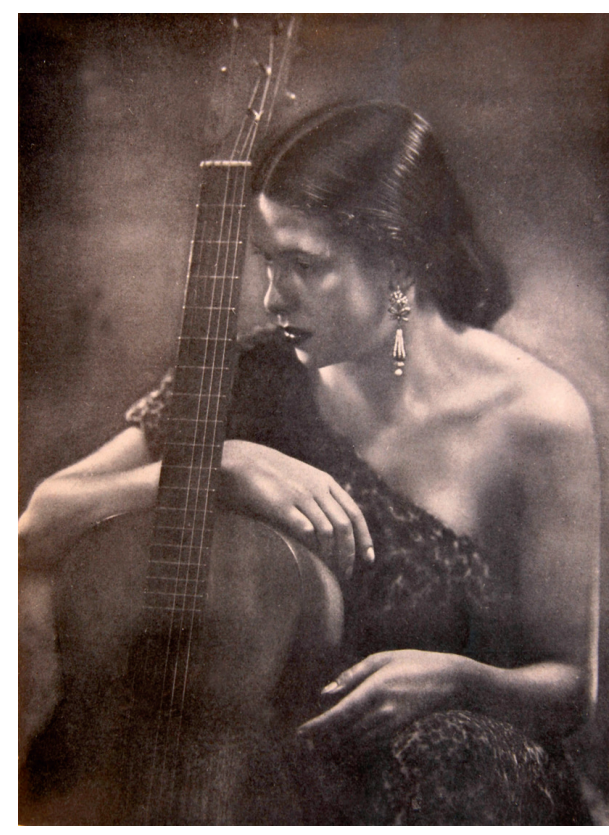

Fig. 4. Daniel Garay. Retrato. Anuario Sombras, 1946.

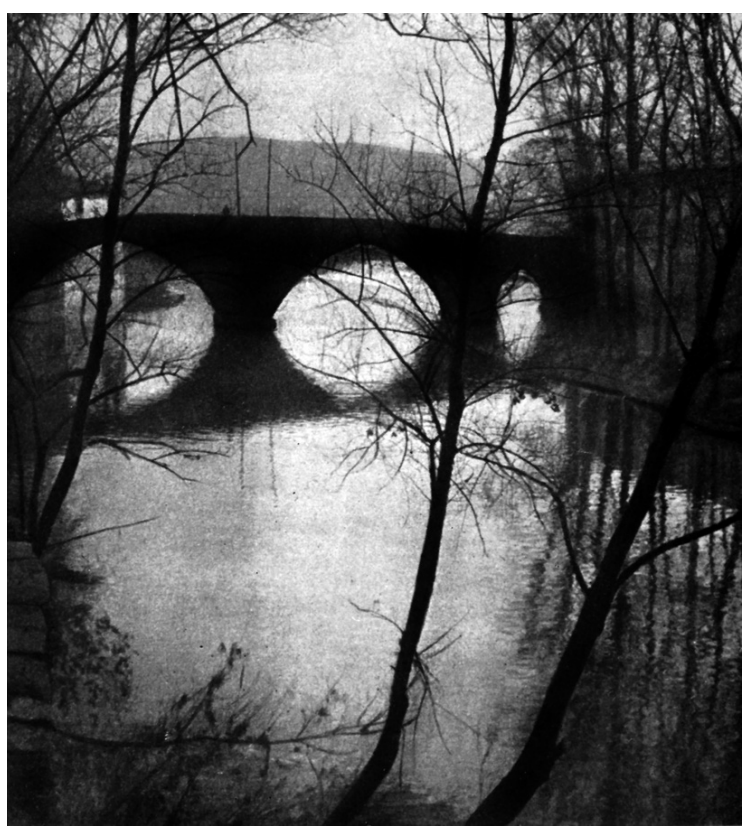

Fig. 5. Conde de la Ventosa. Bruma. Anuario de 1946.

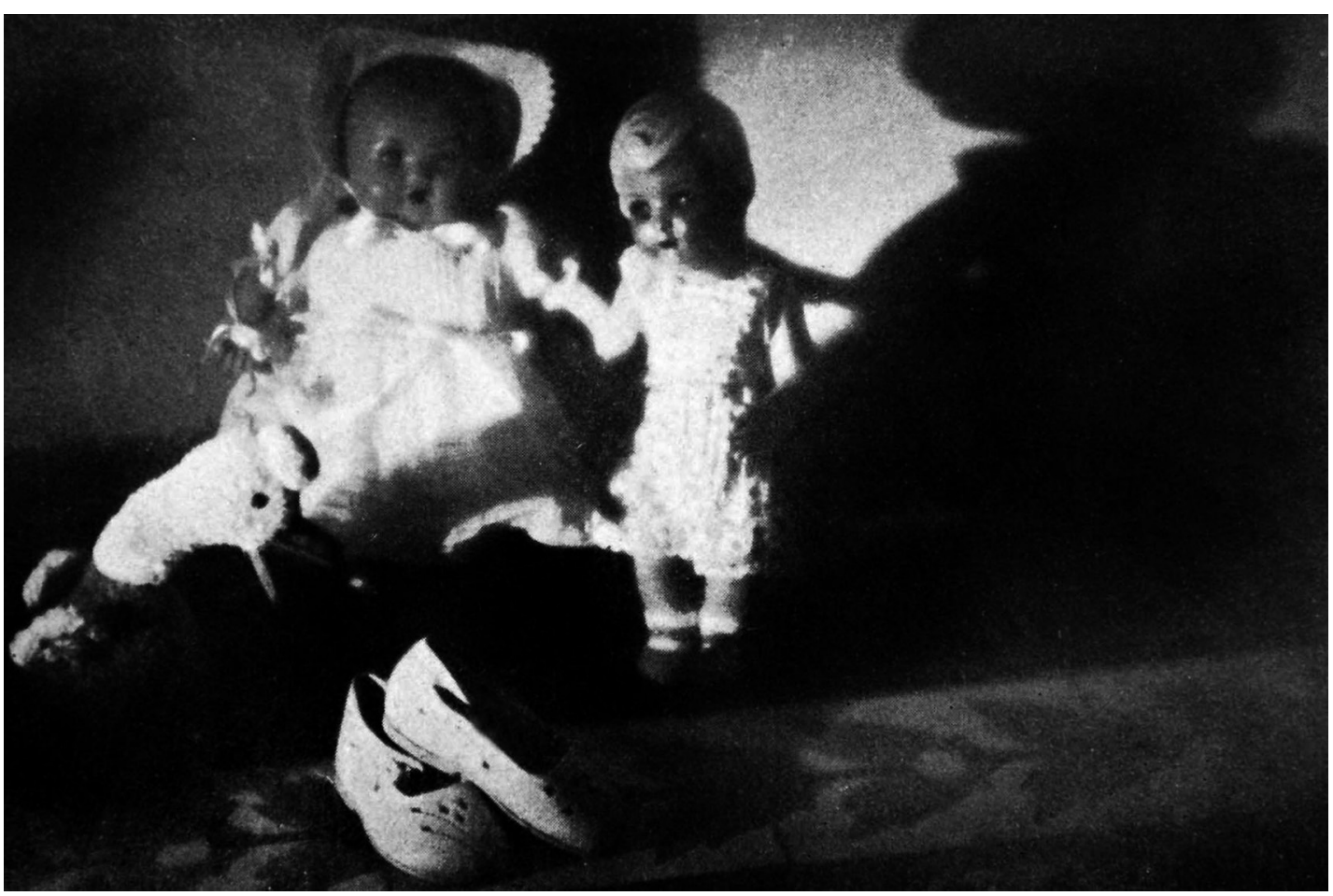

Fig. 6. Diego Gálvez. Amanecer de Reyes. Anuario de 1946.

Arch. esp. arte, LXXXVII, 348, OCTUBRE-DICIEMBRE 2014, 383-400 ISSN: 0004-0428, eISSN: 1988-8511, doi: 10.3989/aearte.2014.24 
La relación de suscriptores a la revista nos permite conocer a gran parte de los profesionales en activo. Se catalogaron 1.599 fotógrafos (anexo 2), con indicación del nombre, localidad y dirección. De ellos 139 pertenecían a Barcelona y 155 a Madrid. Esta relación es de gran interés, ya que el Anuario les atribuye una categoría (redactor y colaboradores de Sombras, expositor nacional y/o internacional, miembro de agrupaciones o sociedades).

La referencia a los proveedores es clave para el conocimiento de la industria y el comercio de fotografía en la posguerra civil española. Tras un largo período de inactividad se produjo un resurgir lento debido a la escasa importación de productos y a la situación económica del país. En 1946 había en España más de seiscientos establecimientos entre fabricantes, distribuidores, comercios y laboratorios. Algunos de estos proveedores aparecen de manera destacada y con publicidad, de lo que se deduce una mejor situación económica que el resto: Casa Sánchez (Alicante); Luis Balta, Campañá, Gaspar Mampel, Soteres y Torras (Barcelona); Espiga (Bilbao); Casa Bosch (Gerona); Aeolian, Athia, Valentín Fernández López, Gan, Román García, Jiménez, López Elizalde, Braulio López, José Ortiz, Peñalara, Sarralde (Madrid); Foto Moda (Sevilla); Casa Manero (Valencia); Óptica Iris (Valladolid); Foto Club y Casa del Aficionado (Vigo); y Cuevas (Zamora).

\section{Anuario de 1948}

El anuario de 1948 fue editado por Biblis y constó de 172 páginas divididas en tres partes: textos, ilustraciones y relaciones de suscriptores, profesionales, proveedores y asociaciones. El diseño fue muy cuidado, con encuadernación en tela gris estampada en seco en dos colores, azul y rojo, y tres tipos de papel para separar los contenidos: el habitual para los textos, cuché para las ilustraciones y de tono rosado para los listados. No se incluyó presentación o prólogo, tampoco se especificaron los objetivos y los criterios de selección de las imágenes, ni se indicaron los autores de los textos, todos de carácter técnico: positivado artístico (diez procedimientos), fórmulas, productos químicos y tipología de objetivos anastigmáticos.

Se reprodujeron 32 fotografías de 27 autores (una por página a modo de lámina), en buena parte procedentes de los concursos mensuales convocados por Sombras (17 fotos) en varios certámenes: Exposición del Nuevo Club Deportivo de Bilbao, Club Excursionista de Gracia, Salón Graciense de Arte Fotográfico y Salón del Foto Club Valencia. Al contrario que en 1946, se apostó por nuevos creadores, ya que tan solo dos autores eran conocidos por su actividad: Toribio Noaín, del que se seleccionó un retrato, y el paisajista Marqués de Santa María del Villar. Carmen Guerra fue la única mujer en los anuarios, de la que se seleccionan dos obras: la primera una toma nocturna de la Plaza Mayor de Salamanca, destacable por las sombras y por el grano, y la segunda una feria de ganado, más convencional en el encuadre (tabla 3).

En cuanto a la temática, presenta cuatro apartados: Retratos (3), Paisajes y vistas (16), Composiciones (6) y Escenas y costumbres (7). La estética responde, al igual que en 1946, al pictorialismo tardío, con escenas rebuscadas y manidas. Se observan algunas modificaciones como la desaparición de los trajes regionales en los retratos, el uso del contraluz como elemento destacable, agudizando las obras, y la primacía de los bodegones de frutas y hortalizas en las composiciones.

Los paisajes, tanto los naturales como los rurales y urbanos, responden al tópico, sin nuevas aportaciones creativas, y los pocos retratos son de escaso interés. De las composiciones destaca la titulada En el estudio, de Felipe Torres (fig. 7), muy vanguardista por el encuadre de los objetos seleccionados (chinchetas) y con influencias de la Nueva Objetividad. De mayor fuerza emocional, pero claramente pictorialistas, son Penitencia de Andrés Oliva (fig. 8) e Infancia de Amadeo Pujol Moragas, con un guiño a la revista Sombras (fig. 9). En cuanto a los retratos, es destacable el titulado Marinero de Enrique Carreras (fig. 10), de impecable composición. 
Tabla 3. Autores del anuario Sombras de 1948.

\begin{tabular}{|l|l|}
\hline \multicolumn{1}{|c|}{ Autor } & \multicolumn{1}{c|}{ Título } \\
\hline Bermejo, Moisés & Nieve \\
\hline Carreras, Enrique & Marinera \\
\hline Cisneros & C/del Arco (Huercal) \\
\hline Estany Vallestín, J. & Nubes de otoño \\
\hline Fatás Ojuel, G. & El último surco \\
\hline Folch Jou, G. & Aspas \\
\hline Foradada, Alfonso & Clausura \\
\hline Guerra Velasco, C. & Feria en Pontevedra \\
\hline Guerra Velasco, C. & Pl. Mayor Salamanca \\
\hline Mejón, Luis & Nocturno en el Prado \\
\hline Merlo Delgado, A. & Aspas \\
\hline Noaín, Toribio & Chomin \\
\hline Oliva, Andrés & Penitencia \\
\hline Panero Pérez, José & Barbechera \\
\hline Pascual Raga, F. & Almoraira la blanca \\
\hline Pastor, Javier & Guindola \\
\hline
\end{tabular}

\begin{tabular}{|l|l|}
\hline \multicolumn{1}{|c|}{ Autor } & \multicolumn{1}{c|}{ Título } \\
\hline Pujol Moragas, A. & Abstracción \\
\hline Pujol Moragas, A. & Sabor de campo \\
\hline Renard, L. & Ramco \\
\hline Rivas Moret, Ant. & Caracol \\
\hline Romero-Rato & Contraluz \\
\hline Rosa Casaco, Ant. & Últimas noticias \\
\hline Rosa Casaco, Ant. & Sede matutina \\
\hline Sánchez-Mata, J.C. & Rochano Manchego \\
\hline Sta. María del Villar & Picos de Europa \\
\hline Sierra Calvo & Bucólica \\
\hline Sierra Calvo & Sinfonía \\
\hline Torres, Felipe & En el estudio \\
\hline Torres, Felipe & Cresterías Monterrey \\
\hline Torres Romero, F & Uvas y manzanas \\
\hline Tubau, Miguel & Carros \\
\hline Valls Más, J. & Luz y sombras \\
\hline
\end{tabular}

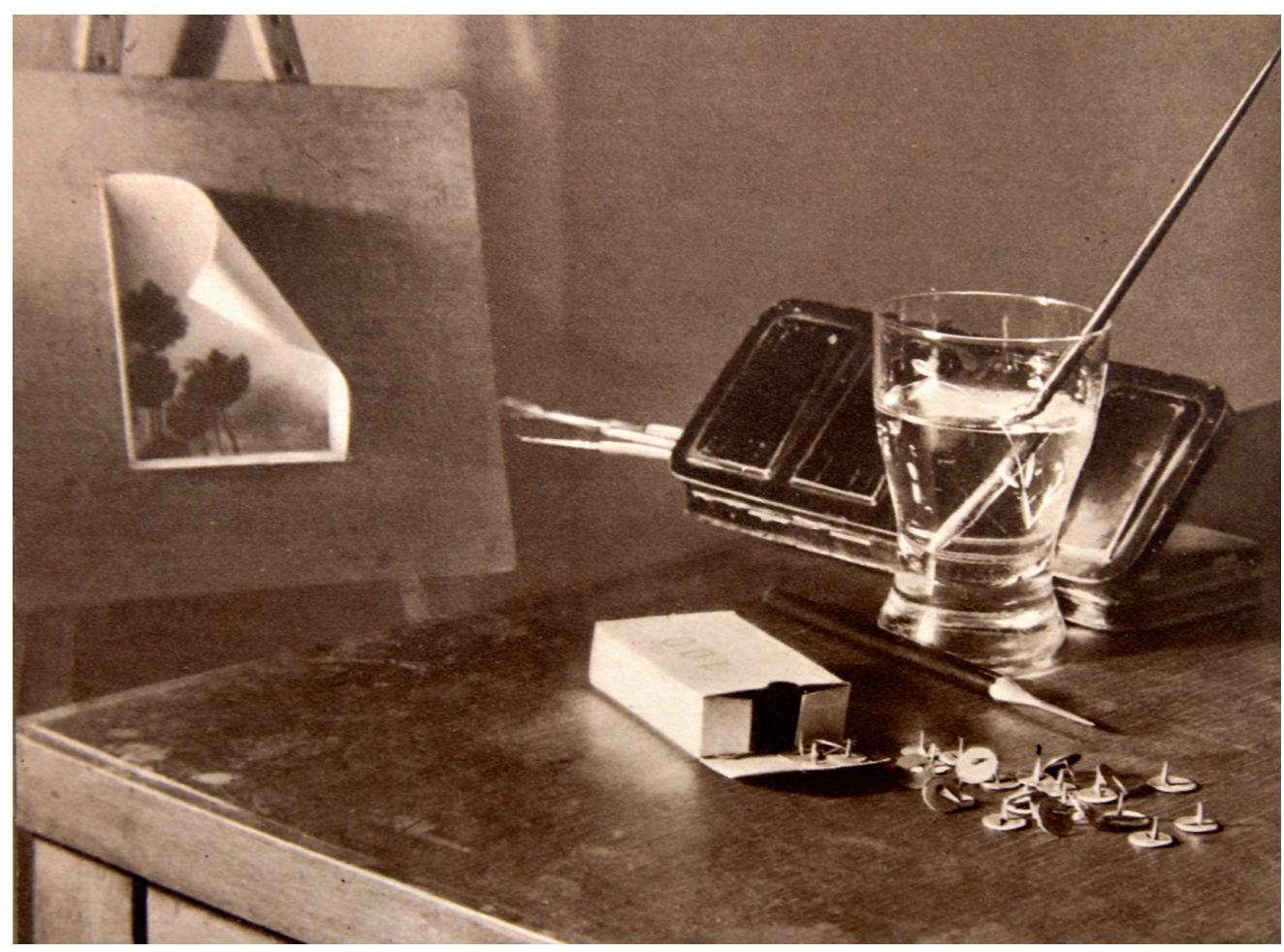

Fig. 7. Felipe Torres. En el estudio. Anuario de 1948.

Arch. esp. arte, LXXXVII, 348, OCTUBRE-DICIEMBRE 2014, 383-400 ISSN: 0004-0428, eISSN: 1988-8511, doi: 10.3989/aearte.2014.24 


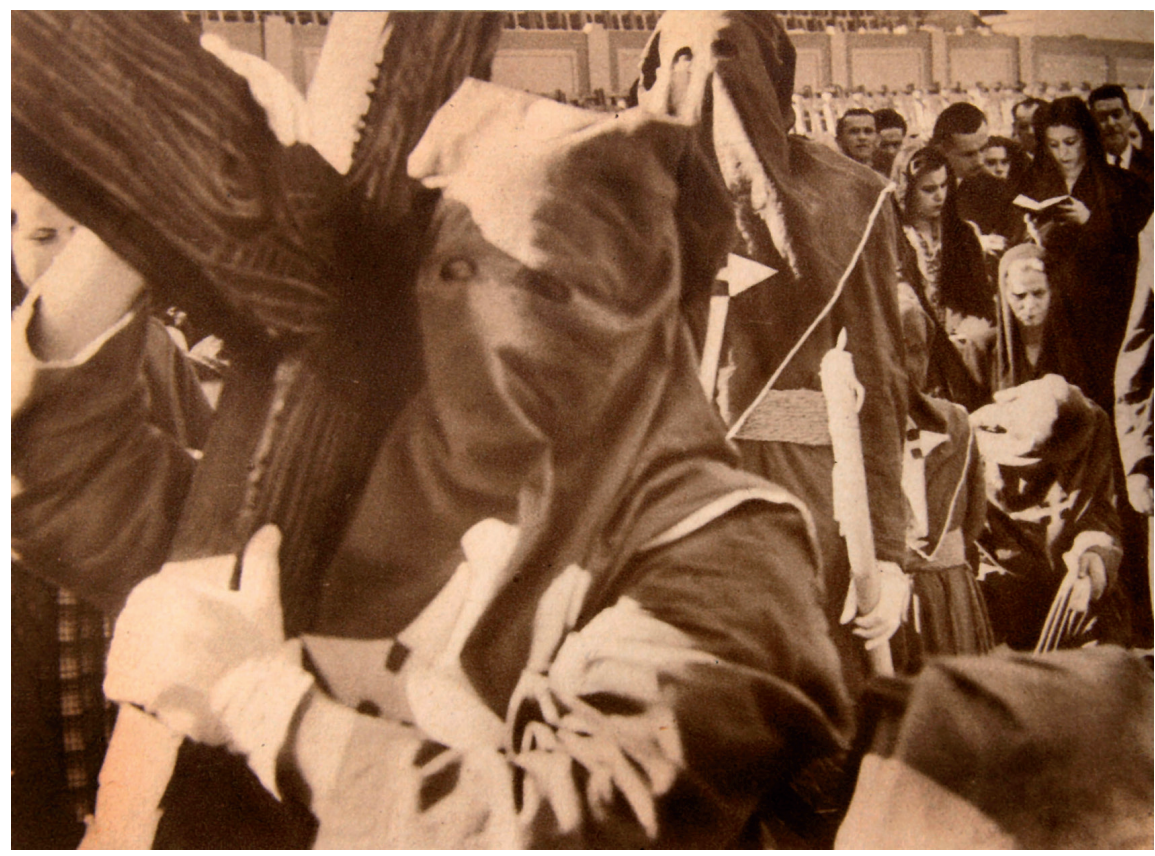

Fig. 8. Andrés Oliva. Penitencia. Anuario de 1948.

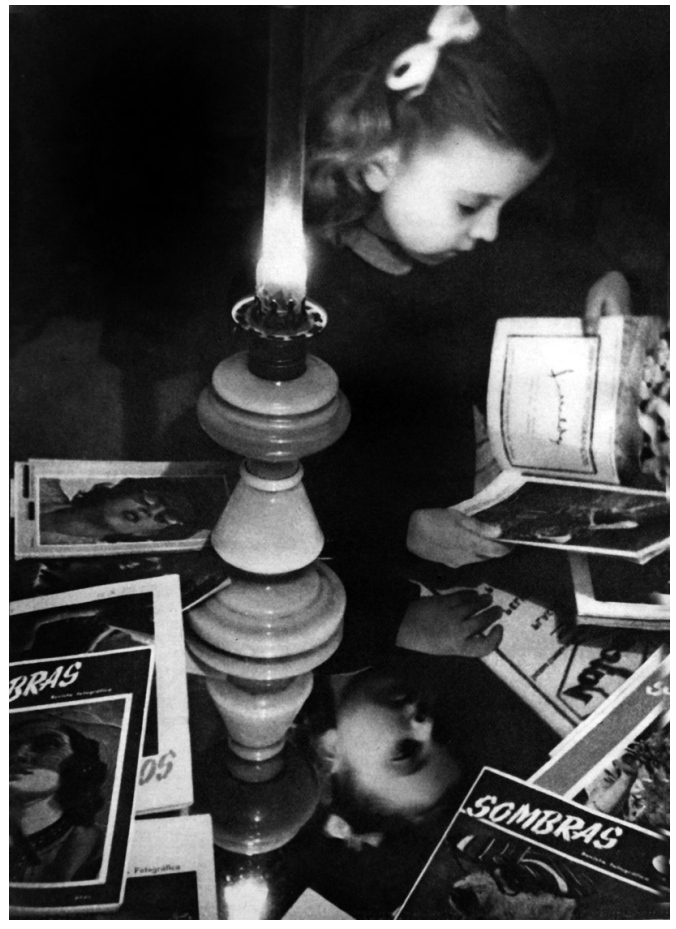

Fig. 9. Amadeo Pujol Moragas. Infancia. Anuario Sombras, 1948.

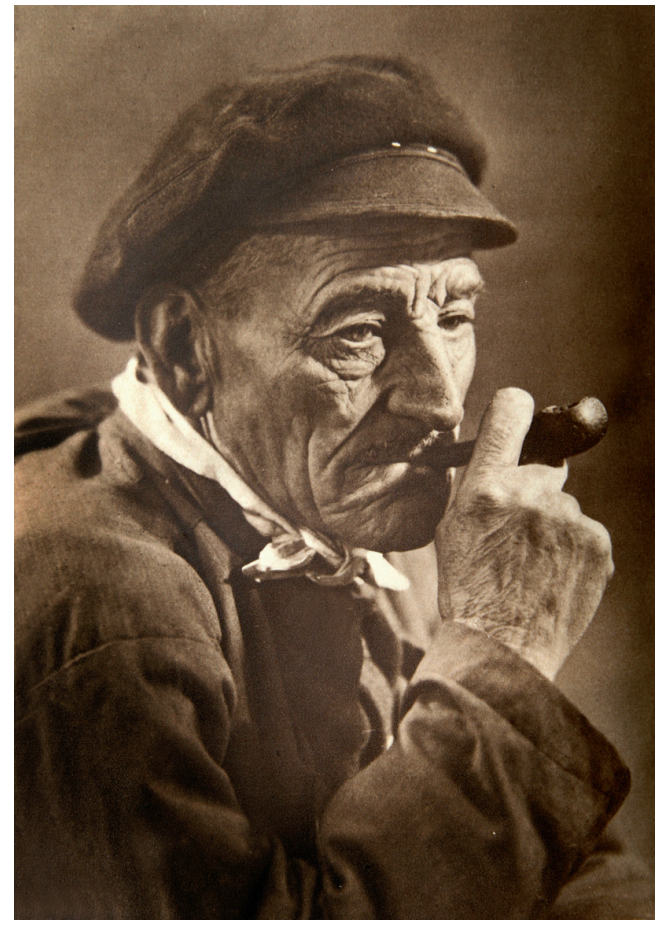

Fig. 10. Enrique Carreras. Marinera. Anuario de 1948.

Arch. esp. arte, LXXXVII, 348, OCTUBRE-DICIEMBRE 2014, 383-400 ISSN: 0004-0428, eISSN: 1988-8511, doi: 10.3989/aearte.2014.24 
Por lo que respecta a las sociedades y agrupaciones (tabla 4), las referencias en el anuario son 14, seis dedicadas exclusivamente a la fotografía y ocho secciones de entidades culturales con diversas actividades, principalmente el excursionismo, tan de moda desde el último tercio del siglo XIX. El papel de estos grupos, vinculados en su mayoría a la investigación científica, fue crucial para el desarrollo de la fotografía en todos los sentidos, no solo por su práctica sino por su aplicación a la docencia y a la divulgación en materias como la medicina, la arqueología o la historia.

Tabla 4. Sociedades y Secciones Fotográficas en el anuario Sombras de 1948.

\begin{tabular}{|l|l|l|}
\hline \multicolumn{1}{|c|}{ Agrupación } & \multicolumn{1}{c|}{ Localidad } & \multicolumn{1}{c|}{ Presidente } \\
\hline Fotográfica de Cataluña & Barcelona (Duque de Victoria 14) & Félix Fornells Puig \\
\hline Fotográfica de Igualada & Igualada (Barcelona, San Jaime 6) & José Bisbal \\
\hline Foto Club de Valencia & Valencia (Paz 26) & Vicente Peydró \\
\hline Peña Fotográfica Elche & Elche (Alicante) & Gabriel R. Chorro \\
\hline Real Sociedad Fotográfica & Madrid (Príncipe 16) & Conde de la Ventosa \\
\hline Fotográfica de Zaragoza & Zaragoza (Plaza de Sas 7) & Lorenzo Almarza \\
\hline \multicolumn{1}{|c|}{ Secciones } & \multicolumn{1}{|c|}{ Localidad } & \multicolumn{1}{c|}{ Presidente } \\
\hline Sociedad Villanueva y Geltrú & Barcelona & Alfonso Foradada \\
\hline Centro Excursionista Cataluña & Barcelona (Plaza del Pino 5) & Juan Pi \\
\hline Club Artístico de Écija & Sevilla & Eloy Herrera Pineda \\
\hline Soc. Econ. de Amigos del País & Málaga & Andrés Oliva \\
\hline Centro Excursionista del Bagés & Manresa (Barcelona, Urgel, 14) & José María Font \\
\hline Club Deportivo Bilbao & Bilbao (Alcalde Recalde 28) & Cándido Fullaondo \\
\hline Montañeros del Club Celta & Vigo & José Delgado \\
\hline Sociedad Alpinismo Peñalara & Madrid (José Antonio 27) & Ramón González \\
\hline
\end{tabular}

Los suscriptores de la revista en el año 1948 eran 1.906, casi doscientos más que en 1946, lo que garantizaba la financiación. Además de las agrupaciones bibliográficas que adquirían las revistas para las bibliotecas de las instituciones, en la relación figuran profesionales de larga trayectoria y prestigio como Alfonso o Calvache en Madrid, Coyne de Zaragoza o Legorgeu en Vizcaya.

\section{Valoración y conclusiones}

De esta investigación resultan nuevos datos para la fotografía española en la década de los años cuarenta sobre autores, tendencias, obras, asociaciones, industria y técnica, que permiten ir completando el vacío en los estudios. El escaso número de autores seleccionados en los anuarios, así como el de obras reproducidas, refleja un estado de la cuestión paupérrimo que contrasta con los cerca de 1.600 profesionales censados en las dos publicaciones.

La comparativa de los datos ofrece como resultado que el número de obras seleccionadas en el anuario de 1924 fue de 50, superior al de las dos publicaciones de Sombras en la posguerra: 
40 en 1946 y 32 en 1948. Del mismo modo, el número de autores se redujo: 50 en 1924, 34 en 1946 y 27 en 1948, una limitación sólo justificable por la decadencia del país, sumido en las consecuencias de la contienda civil.

Los criterios de selección de autores (61 en total) no quedan claros en ningún caso, y si bien con carácter general se pretende mostrar las creaciones del momento, no se comprende que se incluya más de una obra de cuatro de ellos en el anuario de 1948. Los conocidos pictorialistas, cuyas obras se publicaron en 1946, cedieron el espacio a nuevos fotógrafos.

Entre los anuarios de 1946 y 1948 no se repitió ni un solo autor; para el primero se seleccionó una obra por fotógrafo, mientras que en el segundo se publicaron dos obras de cuatro autores (Carmen Guerra Velasco, Amadeo Pujol Moragas, Antonio Rosa Casaco y Felipe Torres) y una del resto. Con relación al anuario de 1924, cuatro autores repitieron en 1946, los citados Andrada, Ortiz Echagüe, el conde de la Ventosa y Susanna, editor de este último. En 1948 solo aparece un fotógrafo del anuario de 1924, el marqués de Santa María del Villar, con un tema característico de su amplia producción paisajística: Picos de Europa. Tan solo aparece una mujer en 1948, Carmen Guerra Velasco, de la que se publicaron dos obras tomadas en Pontevedra y Salamanca. La noticia de su participación en un concurso de la revista Sombras sobre "Rincones típicos", y su exclusión en el censo de profesionales, la presenta como amateur y confirma la mínima participación de las mujeres en la fotografía.

En cuanto a los contenidos, se advierte un interés por equilibrar los textos con las imágenes, procurando incluir las novedades sobre técnica, procedimientos, óptica y revelados. Hemos establecido cuatro categorías de ilustraciones: Retratos, Paisajes, Composiciones y Escenas costumbristas. En tan solo dos años el criterio cambió en la cantidad, pasando de 19 retratos en 1946 a 3 en 1948, y los paisajes de 7 a 16. Las escenas de costumbres (10 y 7 respectivamente) y las composiciones ( 4 y 6 ) mantuvieron la media. El pictorialismo fue la estética predominante, con ciertas influencias de la vanguardia en las composiciones (casos de Aurelio Grasa o Felipe Torres), pero no así en los retratos y paisajes. La característica general es la representación del tópico, con las excepciones señaladas en el texto.

Los proveedores y comerciantes censados en ese período fueron más de 600, de ellos 76 con sede en Barcelona y 40 en Madrid. Varios profesionales de prestigio, además de tener estudio, abrieron comercio para la venta de material, entre ellos Torres Molina (Granada), Espiga (Bilbao), Campañá (Barcelona) o Beringola (Madrid).

Un aspecto de gran interés, por la información que aporta, es el censo de fotógrafos por provincias con indicación de la localidad y dirección en la que ejercieron su actividad, datos que nos permiten conocer las zonas geográficas con mayor y menor implantación de empresas y, en consecuencia, la producción por zonas. Es fundamental asimismo la información sobre proveedores de material y artículos fotográficos, clave para conocer la industria de posguerra.

\section{BIBLIOGRAFÍA}

Alsina Munné, H., Historia de la fotografía, Barcelona, Producciones Editoriales del Nordeste, 1954.

Cánovas, Carlos, "Entre dos rupturas", en Tiempo de silencio. Panorama de la fotografía española de los años 50 y 60, Barcelona, Fundación La Caixa y Generalitat de Catalunya, 1992.

Carabias, Mónica, "Un fragmento teórico de la memoria fotográfica en la posguerra española. La revista Sombras (1944-1952)", en Lars. Cultura y Ciudad, 2009, n. ${ }^{\circ} 15$, pp. 77-81.

Carabias, Mónica, Sombras, Revista fotográfica española, 1944-1954, Madrid, Pentagraf, 2011.

Fernández, Horacio, "Fotografía en revistas y revistas de fotografía", en Arte moderno y revistas españolas, 1898-1936. Madrid, Museo Centro de Arte Reina Sofía, 1996.

Fernández, Horacio, Variaciones en España. Fotografía y Arte 1900-1980, Madrid, La Fábrica, 2004.

Fontcuberta, Joan (editor), Fotografia. Crisis de historia, Barcelona, Actar, 2002. 
Fontcuberta, Joan, Historias de la fotografía española. Escritos 1977-2004, Barcelona, Gustavo Gili, 2008. López Mondéjar, P., Historia de la fotografía en España, Barcelona, Lunwerg, 1997.

López Yepes, J. (editor), Diccionario Enciclopédico de las Ciencias de la Documentación, “Anuario”, Madrid, Síntesis, 2004.

Martín López, Ana María y Muñoz García, Manuel, Historia de la Real Sociedad Fotográfica. Voluntad de fotógrafos, Segovia, Universidad SEK y RSF, 2004.

McCuley, Anne, "Escribir la historia de la fotografía antes de Newhall", en Newhall, Beaumont, Historia de la fotografia, Barcelona, Gustavo Gili, 2002, pp. 300-314.

Molinero Cardenal, Antonio, El óxido del tiempo. Una posible historia de la fotografía. Barcelona, Omnicon, 2001.

Newhall, Beaumont, Historia de la fotografia, Barcelona, Gustavo Gili, 2002.

Ollé Pinell, Antonio. Enciclopedia de la Fotografia, Barcelona, Omega, 1957

Sánchez Vigil, Juan Miguel, Del daguerrotipo a la Instamatic, Gijón, Trea, 2007.

Sánchez Vigil, Juan Miguel, La fotografía en España, Gijón, Trea, 2013.

Siles González, Luisa, "Sobre la fotografía de vanguardia en España”, en Pérez Bravo, J. (ed.), La vanguardia en España, París, Cric \& Ophrys, 1998.

Sougez, Marie Loup, Historia de la Fotografía, Madrid, Cátedra, 2004.

Sougez, Marie Loup; García Felguera, María de los Santos; Pérez Gallardo, Helena; Vega, Carmelo, Historia general de la fotografia, Madrid, Cátedra, 2007.

Torres Díaz, Francisco, Crónica de un siglo de historia de fotografía en España, Madrid, Forren, 1999.

Yáñez Polo, M. A.; Ortiz Lara, L.; Holgado Brenes, J. M. (ed.), Historia de la fotografia española, Sevilla, Sociedad de Historia de la Fotografía Española, 1984.

Anexo 1. Autores y obras del Anuario Fotográfico Español (1924)

\begin{tabular}{|l|l|}
\hline \multicolumn{1}{|c|}{ Autores } & \multicolumn{1}{c|}{ Títulos } \\
\hline Aguiló Casas, M. (Barcelona) & Refugio Ciudadano \\
\hline Algueró, Augusto (Barcelona) & El zinc Caló (El Zíngaro) \\
\hline Andrada, Francisco (Madrid) & Beatas \\
\hline Archilla, P. (Madrid) & Catedral de Toledo \\
\hline Areñas, Rafael (Barcelona) & Retrato \\
\hline Arissa, Antoni (Barcelona) & España Clásica \\
\hline Azcona, José María (Calahorra) & Hacia el Mercado \\
\hline Basas Bardají, Juan (Barcelona) & Nocturno \\
\hline Bausells Brandia, Mateo (Barcelona) & Moll del Peix \\
\hline Belda, J. (Albacete) & Retrato \\
\hline Caldés Arús, V. (Barcelona) & Si esta Ciudadana \\
\hline Cano, P. J. (Melilla) & En el Zoco \\
\hline Castellano, J. (Sevilla) & Uña Cañí \\
\hline Compairé, Ricardo (Huesca) & Alto Aragón \\
\hline Cuesta, F. (Madrid) & Del Puente de Toledo \\
\hline Danís, E. (Madrid) & Uclés (Cuenca) \\
\hline Duarte, G. (Oviedo) & El Maestro Casadó \\
\hline Espadaler, Luis (Barcelona) & Iglesia de Valldoreig \\
\hline Gallifa, M. (Barbastro) & Oración \\
\hline Graupera, J. (Barcelona) & Rincón de mi Tierra \\
\hline
\end{tabular}

Arch. esp. arte, LXXXVII, 348, OCTUBRE-DICIEMBRE 2014, 383-400

ISSN: 0004-0428, eISSN: 1988-8511, doi: 10.3989/aearte.2014.24 
Anexo 1. Autores y obras del Anuario Fotográfico Español (1924) (cont.)

\begin{tabular}{|l|l|}
\hline \multicolumn{1}{|c|}{ Autores } & \multicolumn{1}{c|}{ Títulos } \\
\hline Lasso de la Vega, Manuel F. (Sevilla) & Infraganti \\
\hline Llobet, D. (Sabadell) & La Soledad del Viejo Campanario \\
\hline López, Daniel (Madrid) & Claustro de Belem (Lisboa) \\
\hline López Beaubé, Fernando L. (Ávila) & En la Romería, puesto de caramelos \\
\hline Mañas, José (Albacete) & Descanso \\
\hline Martínez del Carnero, A. (Vigo) & Gerona \\
\hline Martínez Sanz, Vicente (Valencia) & Dómine \\
\hline Massana, Josep (Barcelona) & Estudio \\
\hline Montanya, Pedro (Barcelona) & Marina \\
\hline Novella, Vicente (Valencia) & Retrato \\
\hline Ortiz Echagüe, José (Madrid) & Rosita y su Hermano \\
\hline Prast, Antonio (Madrid) & Idilio \\
\hline Puga (Madrid) & Anochecer \\
\hline Puig Pascual, Esteban (Barcelona) & Coll de Nou Creus (Pirineo Catalán) \\
\hline Retes, Pedro (Madrid) & Piedralabes \\
\hline Revenga, Antonio (Madrid) & Cementerio de Brihuega \\
\hline Reyes, José (Guadalajara) & Cabeza de estudio \\
\hline Sánchez Garća, José (Barcelona) & Vegetación \\
\hline Santa María del Villar, Marqués (Madrid) & Costumbres Navarras \\
\hline Santos Peña, F. (Valladolid) & La Niña de las Uvas \\
\hline Soriano, A. (Madrid) & Rincón de la Moncloa \\
\hline Suñé, S. (Gerona) & Retrato de la Srta. Margarita S. \\
\hline Susanna, Eduardo (Guadalajara) & Las dos Cluecas \\
\hline Tarragó, A. Madrid & La Alambra \\
\hline Torcida, José María (Mytolh's y Granada) & Del Sacro Monte de Granada \\
\hline Torres Molina, Manuel (Granada) & Zambra gitana \\
\hline Trajano (Mérida) & Autorretrato \\
\hline Ventosa, Conde de la (Madrid) & Aguadoras castellanas \\
\hline Vilatobá, Joaquín (Sabadell) & Reposo \\
\hline & \\
\hline
\end{tabular}

Anexo 2. Fotógrafos por provincias en 1946 y 1948

\begin{tabular}{|l|r|r|r|r|r|r|}
\hline \multicolumn{1}{|c|}{ Fotógrafos } & \multicolumn{3}{|c|}{1946} & \multicolumn{3}{c|}{$\mathbf{1 9 4 8}$} \\
\hline Provincia & Capital & $\begin{array}{c}\text { Ciudad } \\
\text { Pueblo }\end{array}$ & Total & Capital & $\begin{array}{c}\text { Ciudad } \\
\text { Pueblo }\end{array}$ & Total \\
\hline Álava & 9 & - & 9 & 9 & - & 9 \\
\hline Albacete & 5 & 23 & 28 & 6 & 22 & 28 \\
\hline Alicante & 17 & 29 & 46 & 17 & 28 & 45 \\
\hline Almería & 9 & 13 & 22 & 9 & 11 & 20 \\
\hline
\end{tabular}


Anexo 2. Fotógrafos por provincias en 1946 y 1948 (cont.)

\begin{tabular}{|c|c|c|c|c|c|c|}
\hline \multirow{2}{*}{\begin{tabular}{|c|} 
Fotógrafos \\
Provincia \\
\end{tabular}} & \multicolumn{3}{|c|}{1946} & \multicolumn{3}{|c|}{1948} \\
\hline & Capital & $\begin{array}{l}\text { Ciudad } \\
\text { Pueblo }\end{array}$ & Total & Capital & $\begin{array}{l}\text { Ciudad } \\
\text { Pueblo }\end{array}$ & Total \\
\hline Ávila & 2 & 5 & 7 & 3 & 5 & 8 \\
\hline Badajoz & 6 & 17 & 23 & 6 & 20 & 26 \\
\hline Baleares & 7 & 27 & 34 & 7 & 27 & 34 \\
\hline Barcelona & 139 & 85 & 224 & 133 & 85 & 218 \\
\hline Burgos & 10 & 10 & 20 & 10 & 9 & 19 \\
\hline Cáceres & 3 & 12 & 15 & 3 & 13 & 16 \\
\hline Cádiz & 6 & 31 & 37 & 6 & 28 & 34 \\
\hline Castellón & 6 & 12 & 18 & 6 & 12 & 18 \\
\hline Ciudad Real & 3 & 24 & 27 & 3 & 23 & 26 \\
\hline Córdoba & 7 & 26 & 33 & 7 & 26 & 33 \\
\hline Coruña & 14 & 26 & 40 & 14 & 25 & 39 \\
\hline Cuenca & 4 & 2 & 6 & 4 & 2 & 6 \\
\hline Gerona & 6 & 38 & 44 & 6 & 36 & 42 \\
\hline Granada & 9 & 12 & 21 & 9 & 12 & 21 \\
\hline Guadalajara & 1 & 1 & 2 & 1 & 1 & 2 \\
\hline Guipúzcoa & 20 & 24 & 44 & 20 & 24 & 44 \\
\hline Huelva & 4 & 10 & 14 & 4 & 10 & 14 \\
\hline Huesca & 2 & 11 & 13 & 2 & 10 & 12 \\
\hline Jaén & 4 & 18 & 22 & 4 & 18 & 22 \\
\hline León & 10 & 14 & 24 & 10 & 14 & 24 \\
\hline Logroño & 11 & 3 & 14 & 11 & 3 & 14 \\
\hline Lérida & 4 & 12 & 16 & 4 & 12 & 16 \\
\hline Lugo & 3 & 20 & 23 & 3 & 19 & 22 \\
\hline Madrid & 155 & 22 & 177 & 158 & 22 & 180 \\
\hline Málaga & 19 & 17 & 36 & 19 & 17 & 36 \\
\hline Marruecos & - & 47 & 47 & - & 46 & 46 \\
\hline Murcia & 9 & 30 & 39 & 9 & 31 & 40 \\
\hline Navarra & 5 & 19 & 24 & 5 & 19 & 24 \\
\hline Orense & 4 & 8 & 12 & 4 & 8 & 12 \\
\hline Oviedo & 12 & 31 & 43 & 12 & 32 & 44 \\
\hline Palencia & 6 & 5 & 11 & 6 & 4 & 10 \\
\hline Las Palmas & 14 & 6 & 20 & 14 & 5 & 19 \\
\hline Pontevedra & 3 & 28 & 31 & 3 & 28 & 31 \\
\hline Salamanca & 11 & 11 & 22 & 11 & 11 & 22 \\
\hline Sta. Cruz Tenerife & 4 & 18 & 22 & 4 & 18 & 22 \\
\hline Santander & 7 & 8 & 15 & 8 & 11 & 19 \\
\hline Segovia & 3 & 2 & 5 & 3 & 2 & 5 \\
\hline
\end{tabular}


Anexo 2. Fotógrafos por provincias en 1946 y 1948 (cont.)

\begin{tabular}{|l|r|r|r|r|r|r|}
\hline \multicolumn{1}{|c|}{ Fotógrafos } & \multicolumn{3}{c|}{$\mathbf{1 9 4 6}$} & \multicolumn{3}{c|}{$\mathbf{1 9 4 8}$} \\
\hline Provincia & Capital & $\begin{array}{c}\text { Ciudad } \\
\text { Pueblo }\end{array}$ & Total & Capital & $\begin{array}{c}\text { Ciudad } \\
\text { Pueblo }\end{array}$ & Total \\
\hline Sevilla & 33 & 15 & 48 & 34 & 12 & 46 \\
\hline Soria & 1 & 1 & 2 & 1 & 1 & 2 \\
\hline Tarragona & 4 & 20 & 24 & 4 & 20 & 24 \\
\hline Teruel & 1 & 2 & 3 & 1 & 2 & 3 \\
\hline Toledo & 4 & 12 & 16 & 4 & 12 & 16 \\
\hline Valencia & 49 & 31 & 80 & 49 & 31 & 80 \\
\hline Valladolid & 15 & 3 & 18 & 15 & 3 & 18 \\
\hline Vizcaya & 18 & 8 & 26 & 18 & 8 & 26 \\
\hline Zamora & 5 & 7 & 12 & 5 & 6 & 11 \\
\hline Zaragoza & 31 & 9 & 40 & 31 & 9 & 40 \\
\hline Total & 734 & 865 & 1.599 & 735 & 853 & 1.588 \\
\hline
\end{tabular}

Fecha de recepción: 19-IV-2013

Fecha de aceptación: 17-VI-2014 